\title{
What Advanced Treatments Can Be Used to Minimize the Production of Sewage Sludge in WWTPs?
}

\author{
Maria Cristina Collivignarelli ${ }^{1}(\mathbb{D})$, Alessandro Abbà ${ }^{2}\left(\mathbb{D}\right.$, Marco Carnevale Miino ${ }^{1}(\mathbb{D}$ and \\ Vincenzo Torretta ${ }^{3, *}$ (D) \\ 1 Department of Civil Engineering and Architecture, University of Pavia, via Ferrata 1, 27100 Pavia, Italy \\ 2 Department of Civil, Environmental, Architectural Engineering and Mathematics, University of Brescia, \\ via Branze 43, 25123 Brescia, Italy \\ 3 Department of Theoretical and Applied Sciences, University of Insubria, Via G.B. Vico 46, 21100 Varese, Italy \\ * Correspondence: vincenzo.torretta@uninsubria.it; Tel.: +39-0332-218782
}

Received: 6 June 2019; Accepted: 27 June 2019; Published: 29 June 2019

\begin{abstract}
Similar to other types of waste, sewage sludge (SS) must be minimized, not only to respect the European Directive 2018/851 on waste, but also because the cost of sludge management is approximately $50 \%$ of the total running costs of a wastewater treatment plant (WWTP). Usually, minimization technologies can involve sewage sludge production with three different strategies: (i) adopting a process in the water line that reduces the production of sludge; (ii) reducing the water content (dewatering processes) or (iii) reducing the fraction of volatile solids (stabilization). This review, based on more than 130 papers, aims to provide essential information on the process, such as the advantages, the drawbacks and the results of their application. Moreover, significant information on the technologies still under development is provided. Finally, this review reports a discussion on the impact of the application of the proposed processes in the sludge line on a WWTP with a capacity exceeding 100,000 population equivalent (PE).
\end{abstract}

Keywords: innovative approach; sewage sludge; wastewater; dewatering; minimization; sludge line; stabilization

\section{Introduction}

Sewage sludge (SS) is a mixture of organic and inorganic matter and its composition strongly depends on the treatment and on the wastewater origin [1]. It can be composed of primary sludge, derived from primary sedimentation and formed by suspended sedimentary materials, secondary sludge, made up of excess biomass and, tertiary sludge, obtained in the advanced wastewater treatment stages, when nutrient (nitrogen and phosphorus) removal is required [2].

In recent years, the population growth and consequent urbanization have increased the number of wastewater treatment plants (WWTPs) and the production of SS [3,4]. Moreover, the application of more stringent requirements for WWTPs effluents quality increases the production, and worsens the quality, of the SS. For instance, in the EU, the implementation of the European Commission Directive 98/15/EC (amending Council Directive 91/271/EEC) led to a strong rise in sludge generation, up to $50 \%$ [5], with an estimate of more than 13 million Mg of dry matter in 2020. According to these data, developing urgent and effective approaches to reduce and recover SS becomes a priority $[6,7]$.

Particularly, in order to respect the European Directive 2018/851 on waste, the first aspect to take into consideration is the minimization of the waste produced [8] and therefore, sludge [9]. Furthermore, the economic aspect has become important in recent years. Researchers show that the cost of sludge management is approximately $50 \%$ of the total running costs of the WWTP with the conventional activate sludge (CAS) process $[10,11]$. Moreover, also in the case of the WWTPs, as 
already suggested in recent years for drinking water treatment plants [12,13], some procedures for evaluating the performance of the plants and for defining optimal solutions for management in order to optimize operation and minimize the production of SS should be studied.

In 2015, 9.7 million $\mathrm{Mg}_{\mathrm{DM}}$ (DM - dry matter) of SS were produced in Europe. More than $60 \%$ of the total SS was produced in Germany (around 19\%) and the western countries (UK, Italy, Spain and France) (Figure 1). By contrast, eastern countries (such as Poland, Romania, Estonia, Latvia and Lithuania) represent around 12\% of SS produced in Europe [14].

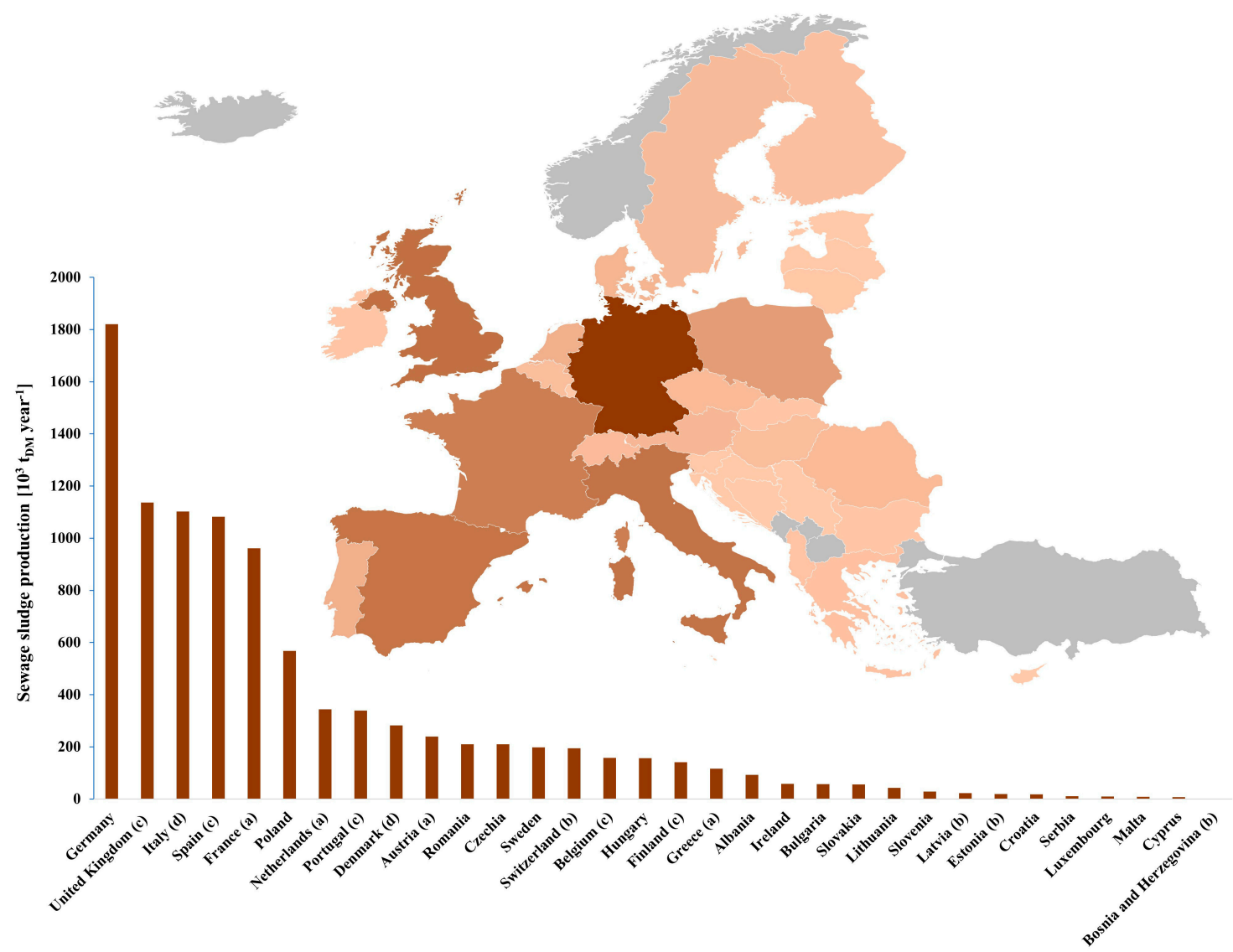

Figure 1. Sewage sludge (SS) production in 2015 in Europe [14]. DM: Dry matter. (a): Data referring to 2014. (b): Data referring to 2013. (c): Data referring to 2012. (d): Data referring to 2010. Data from Turkey, Montenegro, Macedonia, Kosovo, Iceland and Norway are not available.

In the last years, in the EU, SS recovery in agricultural use and composting quickly increased from 3 million $\mathrm{Mg}_{\mathrm{DM}}$ in 1995 (42\% of total production) to 4.2 million $\mathrm{Mg}_{\mathrm{DM}}$ in 2005 ( $54 \%$ of total production); then, this value increased further (5.2 million $\mathrm{Mg}_{\mathrm{DM}}$ in 2010 to $59 \%$ of total production) [14]. The EU issued the Directive 86/278/CEE (recently amended by the EU Decision 2018/853) with the aim of avoiding the application on land of SS that was dangerous for human health. Therefore, every member state has issued a national regulation on this topic [15]. For instance, currently, a high concentration of metals in sludge makes recovery using agriculture impossible [16].

Considering: (i) the framework of the ever-stricter European regulations regarding the recovery of SS in agriculture, (ii) the EU Directive 2018/851 [8] in which minimization is listed as a priority, (iii) the high costs related to SS disposal, it is clear that techniques for minimizing sludge production have become strictly necessary.

In this review, only advanced technologies and treatments are reported. The process description, the advantages, the drawbacks and the results of the literature are presented for each type of treatment. This review provides significant information on the technologies still under development. 


\section{Bibliometric Analysis}

The interest in treatments and technologies in order to minimize the production of SS increased significantly in the last 10 years (Figure 2a). Inserting "minimization sewage sludge" in SCOPUS, only advanced biological treatments were found. Particularly, since 2015, about 83 research papers, reviews, books and conference proceedings on this matter have been published. Among these, biological treatments represent the theme of $39 \%$ of publications, while thermal and chemical treatments stop at $14 \%$ and $16 \%$, respectively. Moreover, the results of the bibliometric analysis show two different trends: (i) the enhanced interest in the combination of different types of treatments and technologies in order to minimize SS (from $21 \%$ to $30 \%$ ) and (ii) the reduction of the study of treatments exclusively of a physical nature. Considering that electrochemical treatments are generally coupled with the use of pressure, in the two periods examined (Figure 2b,c), they have been inserted in the "mixed" category.

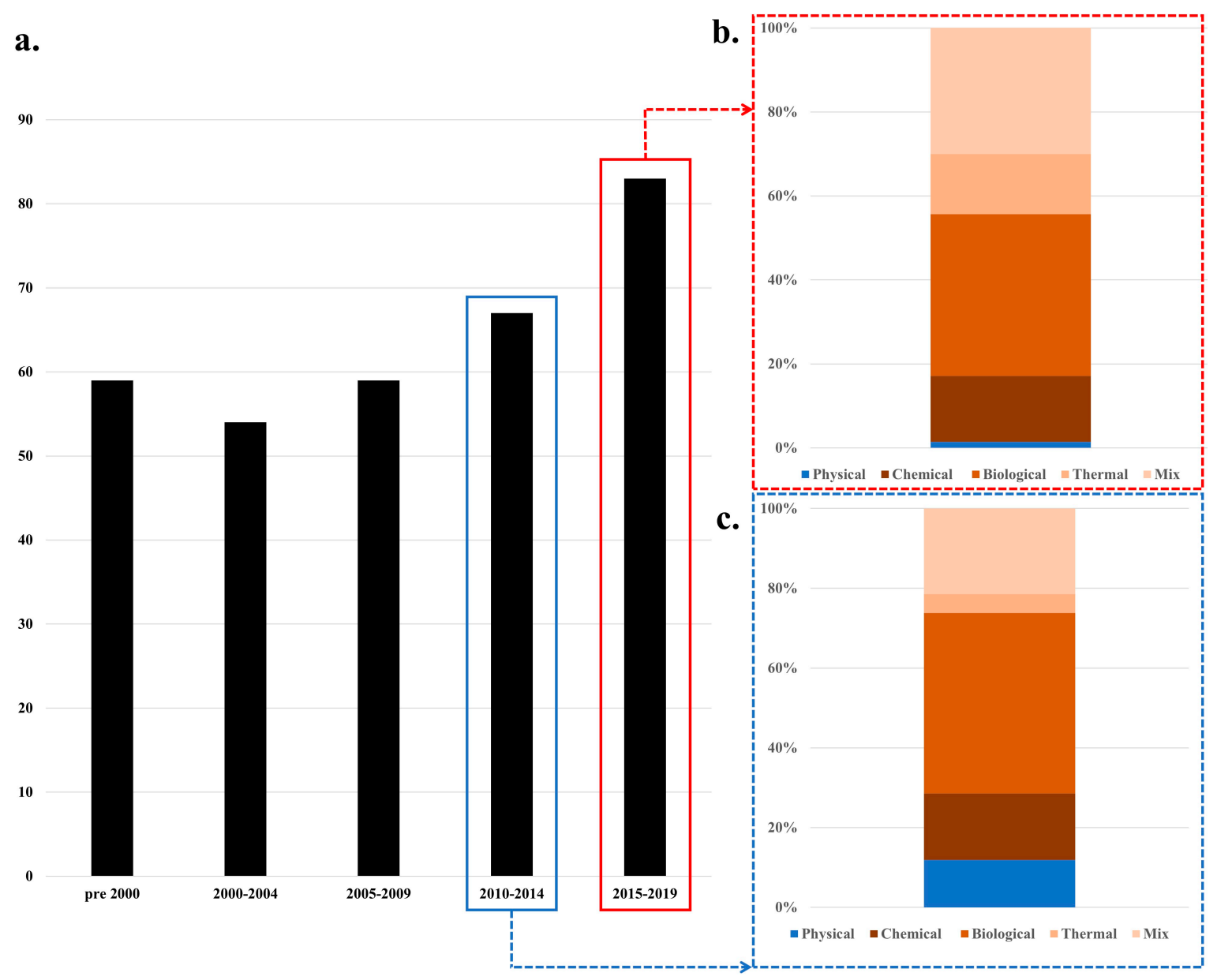

Figure 2. (a) Comparison of the number of research papers, reviews, books and conference proceedings published in the last 20 years and before 2000; (b) Classification of the different types of treatments studied from 2015 to 2019; (c) Classification of the different types of treatments studied from 2010 to 2014. (All data were obtained using the keywords "Minimization sewage sludge" in SCOPUS).

\section{Advanced Treatments and Technologies}

Usually, minimization technologies can involve SS production in three different ways: (i) adopting a process in the water line that reduces the production of sludge; (ii) reducing the water content (dewatering processes) or (iii) reducing the fraction of volatile solids (stabilization). Both interventions in the sludge line and those in the wastewater line are shown (Figure 3), with their respective advantages and downsides. Technical and economic aspects must be evaluated in order to choose the 
most appropriate technology. The advantages and the disadvantages must be considered; not only those direct (i.e., concerning sewage sludge production) but also those indirect (i.e., concerning other aspects of WWTPs). In Figure 4, the suitable advanced treatments available for the minimization of SS production are shown. The patents shown in this document represent, by way of example, those currently on the market. The presence of other patents not mentioned here is not excluded.

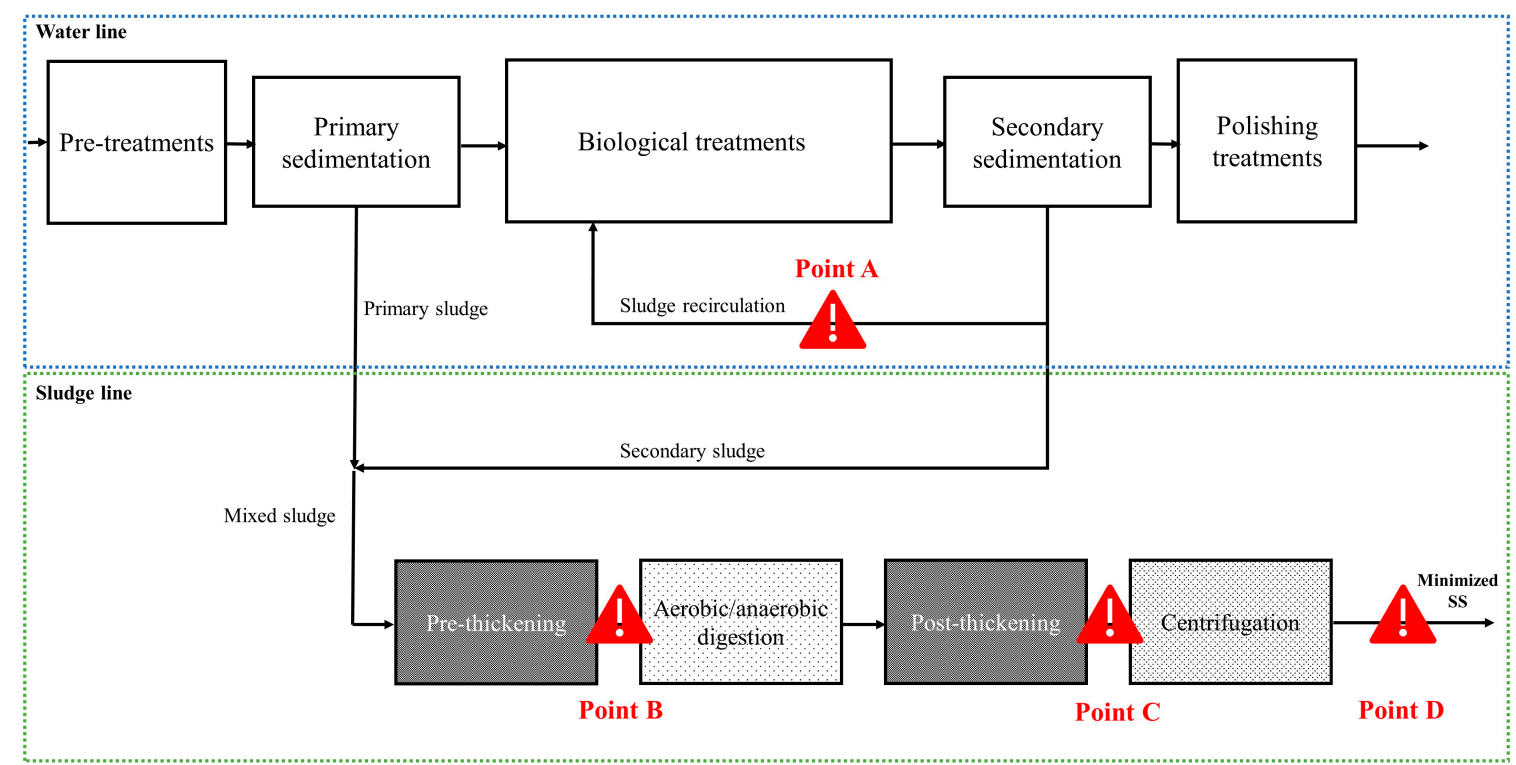

Figure 3. Points of possible application of advanced treatments in a conventional WWTP, in order to minimize the production of SS, in the water line (Point A) and in the sludge line: before hypothetical stabilization (Point B), before hypothetical centrifugation (Point C) and at the end of the line (Point D).

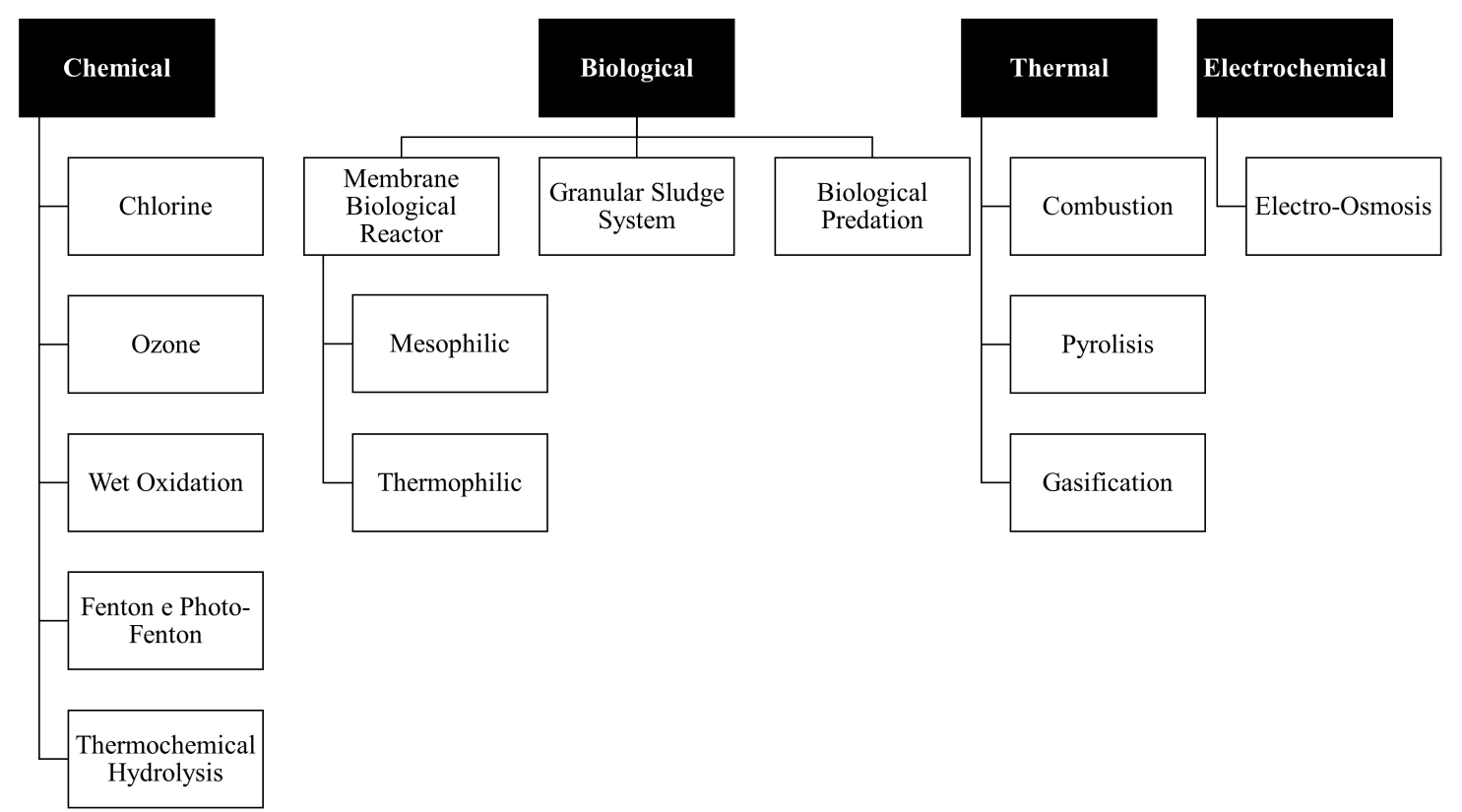

Figure 4. Suitable advanced treatments available for the minimization of SS production are shown.

\subsection{Chemical Treatments}

The most widespread chemical treatment is chemical oxidation, which differs according to the type of reagent used. In order to minimize the SS production, oxidizing the sludge by conventional and advanced chemical reagents, thus reducing the biomass yield as well as the sewage sludge disposal, is 
currently adopted. By chemical oxidation, a part of the activated sludge is mineralized, while another part is solubilized in biodegradable organic compounds which can then be oxidized again in the activated sludge reactor [17-20].

\subsubsection{Ozone and Chlorine}

Among the conventional chemical reagents, the most common are $\mathrm{O}_{3}$ and chlorine [21]. Chemical oxidation can be considered an advanced technique applicable both in the water line, directly on the recirculation sludge, and in the sludge line, after the thickener and upstream of the stabilization [22]. The aim of this treatment is the partial oxidation and hydrolysis of the organic matter, which is transformed into smaller molecular-weight compounds and is therefore more easily biodegradable [23]. Among the main advantages there is the best settleability of the SS [24], the reduction of filamentous microorganisms and the simplicity of plant engineering and management. However, the costs related to investment and oxidizing dose, and the formation of by-products, in particular with chlorine, are the main disadvantages. As regards the performance related to ozonation, there is a reduction in SST from $30 \%$ to $99 \%$ in the water line and from $10 \%$ to $60 \%$ in the sludge line [25]. This great variability, in terms of performance, is influenced by the dosage of oxidizing agent. However, Torregrossa et al. [22] found that ozonation applied in the water line significantly reduced SS production but resulted in a slight decrease of biomass respiratory activity. Gardoni et al. [26] studied the possible application in the sludge line and demonstrated the (non-linear) inverse relationship between ozone dose and specific particulate chemical oxygen demand (COD) solubilisation in the reactor. As concerns the chlorine dosage, the performances obtained by testing synthetic wastewater were lower than $65 \%$ for TSS [25]. Fazelipour et al. [17] studied chlorine application in a sequencing batch reactor (SBR) in order to minimize the SS production. The SBR treatments operate in batch and are composed of five stages: filling, reaction, settling, effluent and idle. The results showed a small dosage of chlorine, equal to 0.26 gchlorine $\mathrm{g}_{\text {MLSS }}{ }^{-1}$ (MLSS-mixed liquor suspended solids), in return excess sludge to the reactor was able to reduce the yield coefficient by $50 \%$. However, as in the case of ozonation applied in the water line, the COD removal percentage in the biological reactor decreased, particularly from $95 \%$ to $56 \%$, due to partial inhibition of biomass caused by the reagent $\left(\mathrm{O}_{3}\right.$, chlorine) dosage. Therefore, the application of chemical oxidation in the water line should be carefully evaluated because even with a low concentration of reagents, partial inhibition of biomass could occur.

\subsubsection{Wet Oxidation (WO)}

Among the chemical oxidation processes, another used and studied is the WO [27-29]. This treatment allows us to obtain a drastic reduction of the organic matter in the SS at certain temperature conditions (150-360 ${ }^{\circ} \mathrm{C}$ ), oxygen concentration (or air) and pressure (30-250 bar) and under continuous process conditions (contact time 15-120 $\mathrm{min}$ ) [25,30,31]. The SS is converted into two products: (i) a gaseous phase and (ii) a liquid phase. This technique can be applied before the dewatering processes because WO can treat sludge with a solid content between $1 \%$ and $6 \%$ [25]. There are already some applications on the real scale thanks to numerous patents. Many variables influence this process and can act interactively. Oxygen stoichiometry is an important factor, and this is significantly influenced by hydrodynamics. Similarly, temperature influences, reaction kinetics, solubility and gas-liquid mass transfer rates depend on the reactor's hydrodynamics [29]. The WO has the advantage of requiring relatively low investment and low energy demand [32]. However, it requires highly qualified personnel able to manage a process that takes place under conditions of temperature and pressure that are certainly not usual. Foladori et al. [25] found that the benefits in this case vary from $70 \%$ to $80 \%$ reduction in terms of TS. Baroutian et al. [28] treated a digested sludge (primary + secondary) for 60 min using $\mathrm{WO}\left(\mathrm{T}=220-240^{\circ} \mathrm{C}\right.$; oxygen: biomass ratio of 1:1-2:1). They found that WO was effective at degrading TSS (86\%) and VSS (96\%). After the experiment, the concentration of oxidizable organic matter was reduced by $98 \%$ of the untreated sludge. 


\subsubsection{Fenton and Photo-Fenton}

The Fenton process is an advanced oxidation process (AOP) useful for minimizing the SS production and increase sludge dewaterability $[33,34]$. This process is composed of four subsequent stages, which are: (i) $\mathrm{pH}$ adjustment at low acidic values, (ii) oxidation, (iii) neutralization and (iv) coagulation [35]. The Fenton reaction produces $\mathrm{OH}^{\bullet}$ in acidic solutions by iron catalysed decomposition of hydrogen peroxide [36]. During the last decade, the possibility of sludge dewatering by Fenton oxidation has been studied and the experimental results indicated that Fenton oxidation had a positive effect $[33,37]$. Moreover, the Fenton process allows us to minimize the SS production. In fact, used as pre-treatment, the Fenton process allows us to increase sludge solubilization and biodegradability, degrading extracellular polymeric substances, and breaking the microbial cell walls [34,38]; therefore anaerobic digestion is improved significantly [33,34,39]. As a result of this application, the volatile solids (VSs) are reduced by $27 \%$, and consequently higher biogas production is achieved [34]. In the literature, the combined application of the Fenton process with biological treatments, such as a membrane biological reactor (MBR), are studied. For instance, He and Wei [40] found that the average sludge yield decreased from $0.15 \mathrm{~g}_{\mathrm{MLSS}} \mathrm{gCOD}^{-1}$ to $0.006 \mathrm{~g}_{\mathrm{MLSS}} \mathrm{gCOD}^{-1}$ during 60 days of operation when an MBR system was combine with the Fenton process.

During recent years, the integration of the Fenton process with ultraviolet or visible light has been investigated in order to increase the stabilization of organic substances and SS dewatering [36,41]. The use of UV rays stimulates the production of $\mathrm{OH}^{\bullet}$ radicals and allows us to re-convert $\mathrm{Fe}^{3+}$ into $\mathrm{Fe}^{2+}$. In this way, the concentration of ferrous ions is increased, and this allows us to further speed up the reaction [42,43]. For instance, Heng et al. [44] tested photo-Fenton pre-treatment followed by anaerobic digestion of secondary sludge and they found 75.7\% total VS reduction, $81.5 \%$ COD removal, and $0.29-0.31 \mathrm{~m}^{3} \mathrm{kgVs}^{-1} \mathrm{~d}^{-1}$ biogas production rate, compared to $40.7 \%$ total VS reduction, $54.7 \%$ COD removal, and $0.12-0.17 \mathrm{~m}^{3} \mathrm{~kg}_{\mathrm{Vs}}{ }^{-1} \mathrm{~d}^{-1}$ biogas production rate without the photo-Fenton pre-treatment. Other applications of photo-Fenton processes for SS are reported in Table 1.

One of the main disadvantages of the Fenton and Photo-Fenton processes is the production of chemical sludge that must be managed and disposed of. In order to minimize this production, zero valent iron in the form of powder (Fe0, ZVI) can also be used as a catalyst in the Fenton process. The most important advantage of this modified Fenton process is the lower chemical sludge production compared to conventional ones [35].

\subsubsection{Thermochemical Hydrolysis (TCH)}

Generally, anaerobic digestion is considered to consist of three steps: hydrolysis, acidification and methanogenesis [45]. In order to promote the dissolution of organic particles and the hydrolysis of organic matters, various pre-treatment methods have been [45-47]. The TCH pre-treatment of sludges for anaerobic digestion increases biogas production, enhances volatile solids reduction, and improves dewaterability of digested sludge [48]. TCH is commonly applied in sludge pre-treatment as it is easy to control, stable in performance, and flexible during operation [47]. It is possible to operate both in the water line (with a reactor arranged on the sludge recirculation) and in the sludge line. The alkaline reagents are the most effective ones [25]. The commonly alkali chemicals used in thermo-alkaline pre-treatment are $\mathrm{NaOH}, \mathrm{KOH}, \mathrm{Ca}(\mathrm{OH})_{2}$ and $\mathrm{Mg}(\mathrm{OH})_{2}$ [45]. As reported by Atay and Akbal [34], in fact, the drawbacks of acidic pre-treatment are: (i) bad odour generation, (ii) possible corrosion of equipment and (iii) potential inhibition to the bacteria involved in digestion. However, in contrast to the alkaline pre-treatment, acidic reagents (e.g., $\mathrm{H}_{2} \mathrm{SO}_{4}$ ) improve the dewaterability of the SS. While the application of the sludge line is decidedly widespread [45,47,48], the application of the water line is not very widely applied at the real scale [25]. In terms of performance, Xie et al. [47] found a higher increase of soluble chemical oxygen demand (SCOD) concentration in the sludge supernatant after $\mathrm{TCH}$ pre-treatment, and the biodegradability of sludge was enhanced greatly.

In Table 1, several applications of chemical treatments are reported. 
Table 1. Several applications of chemical treatments.

\begin{tabular}{|c|c|c|c|c|}
\hline Process & Time [min] & Operative Conditions & Results & Ref. \\
\hline \multirow[b]{2}{*}{$\mathrm{O}_{3}$} & 10 & $\mathrm{O}_{3}=268 \mathrm{mg} \mathrm{L}^{-1}$ & $\mathrm{SSR}=30-35 \%$ & [49] \\
\hline & $1-5$ & $\mathrm{O}_{3}=300 \mathrm{mg} \mathrm{g}_{\mathrm{COD}}{ }^{-1}$ & $\mathrm{SRR}=25-30 \%$ & {$[50]$} \\
\hline Chlorine & n.a. & $\mathrm{ClO}_{2}=2 \mathrm{mg} \mathrm{g}_{\mathrm{TSS}^{-1}}$ & $\mathrm{SRR}=28 \%$ & [51] \\
\hline \multirow{5}{*}{ wo } & 120 & $\begin{array}{l}\mathrm{T}=200-250^{\circ} \mathrm{C} \\
\mathrm{P}_{\mathrm{O} 2}=8-25 \mathrm{~atm} \\
\text { initial TSS }=8 \%\end{array}$ & n.a. & [52] \\
\hline & 60 & $\begin{array}{c}\mathrm{T}=200^{\circ} \mathrm{C} \\
\mathrm{pH}=2 ; \\
\mathrm{P}_{\mathrm{O} 2}=30 \text { bar }\end{array}$ & $\begin{array}{l}\mathrm{COD}_{\text {removal }}=50-70 \% \\
\mathrm{DOC}_{\text {removal }}=20-40 \%\end{array}$ & [53] \\
\hline & 300 & $\begin{array}{c}\text { +thermal hydrolysis; } \\
\mathrm{T}=180^{\circ} \mathrm{C} ; \\
\mathrm{pH}=3.3\end{array}$ & $\begin{array}{c}\mathrm{COD}_{\text {removal }}=58 \% \\
\mathrm{VSS}_{\text {removal }}=20-40 \%\end{array}$ & [54] \\
\hline & 30 & $\begin{array}{c}\mathrm{T}=240^{\circ} \mathrm{C} ; \\
\mathrm{P}_{\mathrm{O} 2}=60 \mathrm{bar} ;\end{array}$ & $\mathrm{TSS}_{\text {removal }}=80 \%$ & [55] \\
\hline & 60 & $\mathrm{~T}=240^{\circ} \mathrm{C}$ & $\begin{aligned} \mathrm{TSS}_{\text {removal }} & =85 \% \\
\mathrm{VSS}_{\text {removal }} & =95 \%\end{aligned}$ & [55] \\
\hline \multirow{4}{*}{ Fenton } & n.a. & $\begin{array}{c}\text { +thermophilic anaerobic digestion; } \\
\mathrm{Fe}^{2+}=0.067 \mathrm{~g} \mathrm{~g}_{\mathrm{H} 202}{ }^{-1} \\
\mathrm{H}_{2} \mathrm{O}_{2}=60 \mathrm{~g} \mathrm{~kg}_{\mathrm{DM}}^{-1} \\
\mathrm{pH}=3\end{array}$ & $\begin{array}{l}\text { The DM values decreased by } 28.2 \% \text {. } \\
\text { The VS values decreased by } 26.8 \% \text {. }\end{array}$ & [34] \\
\hline & 60 & $\begin{array}{c}\mathrm{Fe}^{2+}=200 \mathrm{mg} \mathrm{L}^{-1} \\
\mathrm{H}_{2} \mathrm{O}_{2}=8 \mathrm{~g} \mathrm{~L}^{-1} \\
\mathrm{pH}=3\end{array}$ & $\begin{array}{l}\text { Soluble COD increase from } 38 \text { to } \\
\qquad 2213 \mathrm{mg} \mathrm{L}^{-1}\end{array}$ & [34] \\
\hline & n.a. & $\begin{aligned} \mathrm{Fe}^{2+} & =4 \mathrm{~g} \mathrm{~kg}_{\mathrm{DM}^{-1}} \\
\mathrm{H}_{2} \mathrm{O}_{2} & =60 \mathrm{~g} \mathrm{~kg}_{\mathrm{DM}^{-1}}^{-1}\end{aligned}$ & $\mathrm{SSR}=25 \%$ & [39] \\
\hline & 60 & $\begin{aligned} \mathrm{Fe}^{2+} & =4 \mathrm{~g} \mathrm{~kg}_{\mathrm{TS}}{ }^{-1} \\
\mathrm{H}_{2} \mathrm{O}_{2} & =40 \mathrm{~g} \mathrm{~kg}_{\mathrm{TS}}^{-1} \\
\mathrm{pH} & =3\end{aligned}$ & $\begin{array}{l}\text { Sludge disintegration increased up } \\
\text { to } 23.6 \% \text { and total methane } \\
\text { production with anaerobic } \\
\text { digestion increased up to } 26.9 \%\end{array}$ & [38] \\
\hline \multirow{5}{*}{ Photo-Fenton } & 360 & $\begin{array}{c}\mathrm{Fe}^{2+}=40 \mathrm{mg} \mathrm{L}^{-1} \\
\mathrm{H}_{2} \mathrm{O}_{2}=4 \mathrm{~g} \mathrm{~L}^{-1} \\
\mathrm{pH}=3\end{array}$ & $\begin{array}{l}\text { The soluble COD increased to its } \\
\text { maximum value. }\end{array}$ & [34] \\
\hline & 240 & $\begin{array}{l}\text { Solar Photo-Fenton; } \\
\text { pH = 3; } \\
\mathrm{Fe}^{2+}=40 \mathrm{mg} \mathrm{L}^{-1} \\
\mathrm{H}_{2} \mathrm{O}_{2}=4 \mathrm{~g} \mathrm{~L}^{-1}\end{array}$ & COD solubilization $=4.62 \%$ & [56] \\
\hline & 45 & $\begin{array}{c}\mathrm{Fe}^{2+}: \mathrm{H}_{2} \mathrm{O}_{2}=1: 6 \\
\mathrm{pH}=3\end{array}$ & Solid reduction $=64 \%$ & [57] \\
\hline & 20 & $\begin{array}{c}\text { thomogenizer; } \mathrm{Fe}^{2+}: \mathrm{H}_{2} \mathrm{O}_{2}=1: 6 \\
\mathrm{pH}=3\end{array}$ & Solid reduction $=73.5 \%$ & [57] \\
\hline & 40 & $\begin{array}{c}\text { +post anaerobic digestion; } \\
\mathrm{H}_{2} \mathrm{O}_{2}=725 \mathrm{~g}_{\mathrm{H} 2 \mathrm{O} 2} \mathrm{~kg}_{\mathrm{TS}}{ }^{-1} ; \\
\mathrm{H}_{2} \mathrm{O}_{2} / \mathrm{Fe}^{2+}=80\end{array}$ & $\begin{array}{l}\text { Total VS reduction }=76 \% \\
\quad \mathrm{COD}_{\text {removal }}=81.5 \%\end{array}$ & [44] \\
\hline \multirow{5}{*}{$\begin{array}{c}\text { TCH } \\
\text { (+anaerobic } \\
\text { stabilization) }\end{array}$} & 30 & $\begin{array}{c}\mathrm{T}=121^{\circ} \mathrm{C} \\
\mathrm{NaOH}=7 \mathrm{~g} \mathrm{~L}^{-1}\end{array}$ & $\begin{array}{l}\mathrm{COD}_{\text {reduction }}=89 \% \text {; Total VS } \\
\text { reduction }=77.5 \% ; \text { methane } \\
\text { yield }=0.52 \mathrm{~m}^{3} \mathrm{~kg}_{\mathrm{VS}}{ }^{-1} \\
\text { methane biogas content }=79.5 \%\end{array}$ & [46] \\
\hline & 120 & $\begin{array}{c}\mathrm{T}=70^{\circ} \mathrm{C} \\
\mathrm{NaOH}=5 \mathrm{~mol} \mathrm{~L} \mathrm{~L}^{-1} \\
\mathrm{pH}=12\end{array}$ & VFAs production $=7.5 \mathrm{~g}_{\mathrm{VFAs}} \mathrm{L}^{-1}$ & [45] \\
\hline & 120 & $\begin{array}{c}\mathrm{T}=70^{\circ} \mathrm{C} \\
\mathrm{Ca}(\mathrm{OH})_{2}=4 \mathrm{~mol} \mathrm{~L}^{-1} \\
\mathrm{NaOH}=1 \mathrm{~mol} \mathrm{~L}^{-1} \\
\mathrm{pH}=12\end{array}$ & VFAs production $=6.9 \mathrm{gVFAs} \mathrm{L}^{-1}$ & [45] \\
\hline & 120 & $\begin{aligned} \mathrm{T} & =70^{\circ} \mathrm{C} ; \\
\mathrm{CaO}_{2} & =4 \mathrm{~mol} \mathrm{~L}^{-1}\end{aligned}$ & VFAs production $=7.9 \mathrm{~g}_{\mathrm{VFAs}} \mathrm{L}^{-1}$ & [45] \\
\hline & $<30$ & $\begin{aligned} & +\mathrm{H}_{2} \mathrm{O}_{2} ; \\
\mathrm{T} & =90-135^{\circ} \mathrm{C}\end{aligned}$ & VS removal = 46-66\% & [58] \\
\hline
\end{tabular}

DM: Dry matter; VS: Volatile solids; SSR: Sludge solubilization rate; SRR: Sludge reduction ratio; WO: Wet oxidation; COD: Chemical oxygen demand; DOC: Dissolved oxygen carbon; VSS: Volatile suspended solids; TSS: Total suspended solids; TS: Total solids; TCH: Thermochemical hydrolysis; VFAs: Volatile fatty acids; n.a.: Not available. 


\subsection{Biological Treatments}

\subsubsection{Membrane Biological Reactor (MBR)}

In MBR systems, the separation of the sludge from the effluent takes place in highly efficient membrane modules instead of the traditional secondary sedimentation $[59,60]$. The expected production of sludge in an MBR system is usually lower than in CAS systems, due to the high concentration of biomass in the tank (7-20 g $\left.\mathrm{g}_{\mathrm{TSS}} \mathrm{L}^{-1}\right)$, the low Food/Microorganism (F/M) ratio and, consequently, a high sludge retention time (SRT). Therefore, under these conditions, cell growth is not promoted [25].

\section{- Mesophilic Membrane Bioreactor (MMBR)}

In recent years, MMBR technology has been proposed as a suitable alternative to CAS because of its higher effluent quality, smaller volumes and a lower amount of sludge production [61-63]. The mesophilic temperature conditions vary in a range between 20 and $45^{\circ} \mathrm{C}$ [64]. Being an MBR, this process can be considered a hybrid of a conventional biological treatment system and physical liquid-solid separation using membrane filtration [65]. In MMBR, differently from CAS, the reduction of sludge production appears to be due to the development of predators in the tank, but the opinions on this are discordant [25]. The MMBR technology provides the following advantages over CAS: higher quality effluent for water reuse since bacteria and suspended solids will be retained by membrane, higher volumetric loading rates, shorter hydraulic retention times, longer solid retention times [65-67]. Another advantage of MMBR over CAS systems is the small space required due to the absence of a secondary clarifier and the higher volumetric conversion rates $[65,68]$. The higher volumetric conversion rates are the result of higher biomass concentrations [68]. However, membrane fouling, attributable to high concentrations of TSS, colloids and sludge flocs, remains a significant drawback of MMBR, as it significantly reduces membrane performance and useful life $[25,66,69]$. It leads to an increase in operation costs and a limitation in the transfer of oxygen [25].

Moreover, sludge derived from CAS and MMBR systems results in different dewatering efficiency according to Pontoni et al. [70]. This aspect has been studied by Capodici et al. [61]. The achieved results confirmed the complexity of the inter-relationships between many factors affecting the sludge dewaterability. Capodici and Mannina [71] confirmed that the literature reports differ and there are contrasting data on the best or worst sludge dewaterability from MMBR compared to that from CAS. However, Pontoni et al. [70] affirmed that MMBR configuration produced a sludge with a lower mean particle size respect to the CAS and, therefore, worse dewaterability properties. On the contrary, Pontoni et al. [72] tested the effect of anaerobic digestion on dewatering properties in MMBR and CAS. They found that worsening effect due to the post anaerobic digestion is decidedly lower for MMBR sludge with respect to CAS. Several authors also investigated the possibility of adopting suitable sludge retention times in the tank in order to achieve zero net growth [73,74]. Moreover, in the last decade, MMBR systems have been coupled with other disintegration treatments (e.g., ozonation, ultrasonication) in order to increase the biomass decay rate, maintaining a relatively low concentration of TSS in the MMBR system [25,75,76]. Foladori et al. [25] reported that these applications, which can only be used in the water line, make it possible to achieve a reduction of $99 \%$ in terms of TSS.

\section{- Thermophilic Membrane Bioreactor (TMBR)}

The TMBR represents an evolution of MMBR. In this case, a membrane system (generally ultra or nano-filtration) is coupled to the thermophilic biological process. This aspect allows us to overcome the problem due to the poor settleability characteristics of the thermophilus biomass. Thermophilic microorganisms show optimal growth at temperatures of $50{ }^{\circ} \mathrm{C}$ or higher [77]. There is little knowledge about microbiological species in sludge subject to thermophilic processes. In fact, only some species like Bacillus have been identified by researchers [78,79]. Moreover, only in recent years has the impact of the operational parameters on the process under thermophilic conditions been investigated [80]. The membrane fouling represents a significant issue in this treatment. 
For instance, Collivignarelli et al. [81] found that increasing the SRT, the membrane fouling rate decreased. The operative conditions can be different: (i) aerated, (ii) non-aerated or (iii) alternate $[11,81]$. In order to reduce the production of SS, this system can be applied both in the water line (replacing the CAS) [80] and sludge line $[11,81]$. Generally, aerobic conditions are applied if this treatment is used in the water line to treat COD-rich liquid waste (specific lower sludge production) [82-84], while anaerobic or alternate conditions are applied in the sludge line treatment [11]. To date, the application to the real scale concerns two plants in Italy. The reduction in the sludge production varies from $70 \%$ to $90 \%$ in terms of VS for the treatment of municipal sludge, while from $50 \%$ to $65 \%$ for those with a strong industrial component $[11,25]$. This reduction is due to a low specific production of biomass (0.05-0.3 $\mathrm{kg}_{\mathrm{VSS}}$ produced per $\mathrm{kg}_{\mathrm{COD}}$ removed) [83].

\subsubsection{Granular Sludge Systems (GSS)}

GSS includes anaerobic granular sludge systems (AnGSS) and aerobic granular sludge systems (AeGSS). AnGSS have been largely applied and have achieved good results in the treatment of high concentration organic wastewater [84]. AeGSS are currently under study [84-88]. In granular systems, a specific production of sludge was observed in the order of $0.07-0.15 \mathrm{~kg}_{\mathrm{TSS}} \mathrm{kgCOD}_{\text {removed }}{ }^{-1}$, compared to $0.27-0.35 \mathrm{~kg}_{\text {TSS }} \mathrm{kgCOD}_{\text {removed }}{ }^{-1}$ of the traditional activated sludge [25]. These results were confirmed by Di Iaconi et al. [89-92], who found a specific production of sludge of $0.16 \mathrm{~kg}_{\text {TSS }}$ $\mathrm{kg}_{\text {CODremoved }}{ }^{-1}$ in treating municipal wastewater. An example of a plant of this type has been set by the CNR and is known as the sequencing batch biofilter granular reactor (SBBGR) system $[89,90]$.

The experimental results obtained showed that the plant, fed with the effluent exiting the primary sedimentation of an urban WWTP, presented high yields of COD removal, of total suspended solids and of nitrogen (all higher $80 \%$ ), allowing compliance with the discharge limits established by current legislation. The process was characterized by a very low sludge production $\left(0.12-0.14 \mathrm{~kg}_{\mathrm{TSS}} \mathrm{kg}_{\text {CODremoved }}{ }^{-1}\right)$, with respect to CAS, due to the high SRT in the system (>120 d) [91]. A significant advantage of the SBR configuration is that the use of a traditional or integrated settler is not necessary. The separation of sludge and effluent occurs within the reactor during a short settling phase [93]. Therefore, the SBBGR system does not require the presence of a secondary decanter [91,93]. The main disadvantage of these systems is the relatively high investment costs. In fact, de Bruin et al. [93] studied the possible alternative to CAS represented by AeGSS. From an economic point of view, they found that it is very promising technology, and should therefore be further developed, but at the moment has higher costs than CAS. Di Iaconi et al. [91] found that this process allows us to reduce TSS, with yields ranging from $80 \%$ to $90 \%$.

\subsubsection{Biological Predation (BP)}

$\mathrm{BP}$ indicates the consumption of excess sludge by higher organisms such as protozoa and metazoa [34,94]. This process can be applied both in the water line and in the sludge line. If it is applied in the water line, it requires a two-stage system: (i) the first has a short hydraulic retention time (HRT), in order to favour the proliferation of rapidly growing bacteria for wastewater treatment; (ii) the second has a long SRT in order to favour the growth of predators $[25,95]$. For instance, among the protozoa, the ciliate species have a predatory effect on the microfauna of CAS [96]. Wei et al. [95] reported the results of a lab-scale application of a two-stage system with a temperature of $30^{\circ} \mathrm{C}$ and a $\mathrm{pH}$ of 7 . Using bacteria Pseudomonas fluorescens and Tetrahymena pyriformis, they observed sludge reduction yields from $12 \%$ to $43 \%$. The main disadvantages of this application are the significant volume required for the second stage reactor due to the high SRT [94] and the difficulty controlling the growth and reproduction of protozoa and metazoa in the biological system [25]. Other authors studied the application of this treatment in the sludge line. In this case, metazoa, particularly worms and larvae, are preferred to protozoa. Eisenia foetida and Hermetia illucens are the most used. For instance, Kalová and Borkovcová [97] applied Hermetia illucens in order to minimize the production of primary and secondary SS; after 35 days of process, the wet weight had been reduced by $16 \%$. Guo et al. [98] highlighted that, for a full-scale application, the instability of the worm reactor represents the major 
disadvantage. They reported that some researchers have brought up some possible solutions to this problem. For instance, they explained that a 75\% decrease in the amount of TSS was observed in an optimized reactor with Lumbriculus variegatus.

In Table 2, several applications of biological treatments are presented.

Table 2. Several applications of biological treatments.

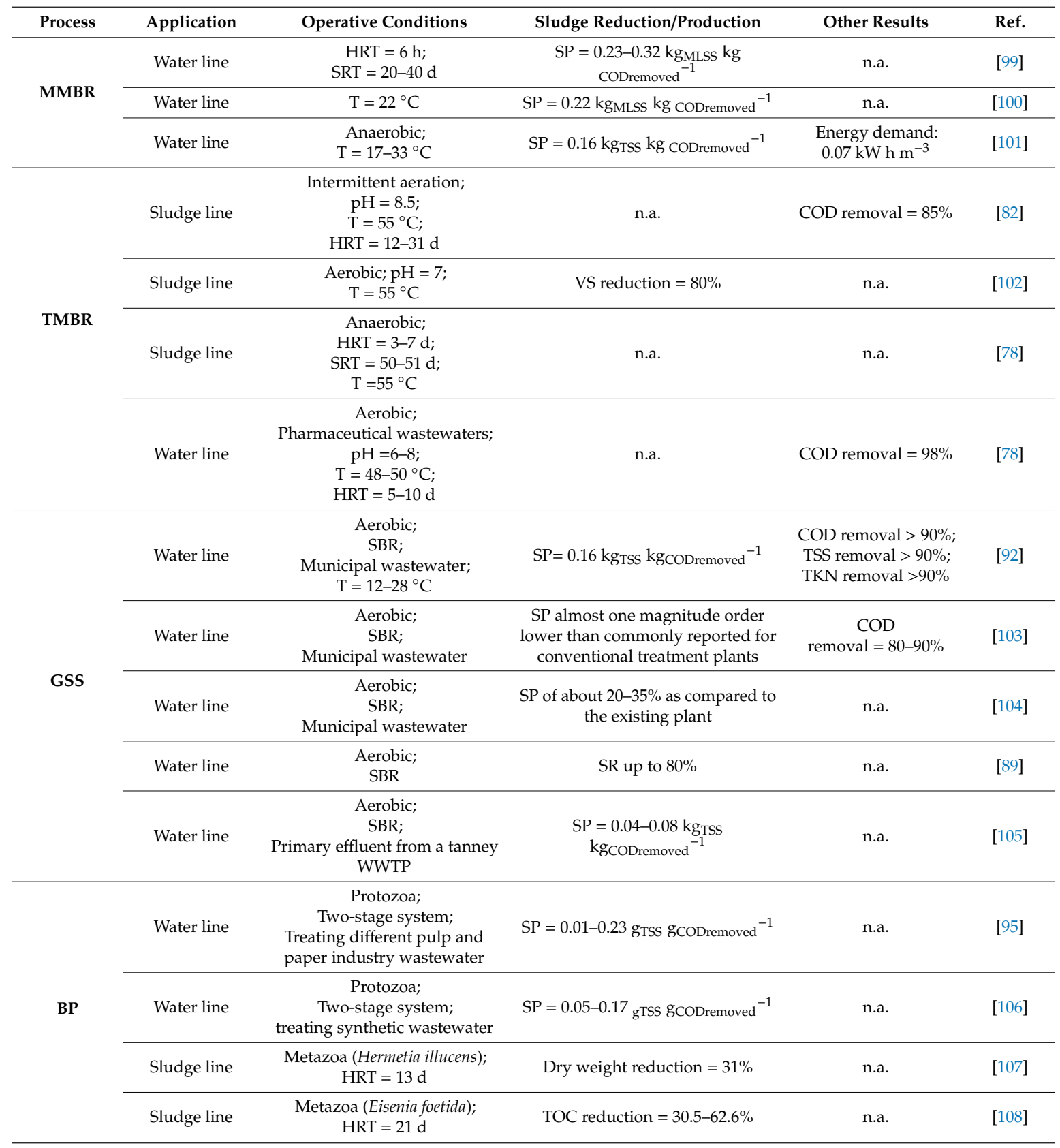

HRT: Hydraulic retention time; SRT: Ludge retention time; SP: Sludge production; MLSS: Mixed liquor suspended solids; COD: Chemical oxygen demand; VS: Volatile solid; TOC: Total organic carbon; SBR: Sequencing batch reactor; TKN: Total kjeldahl nitrogen; SR: Sludge reduction; TSS: Total suspended solids; n.a.: Not available.

\subsection{Thermal Treatments}

The thermal treatments (i.e., combustion, pyrolysis and gasification) intervene with the production of SS, reducing the water content and the fraction of volatile solids. In recent years, the applications of these processes within the WWTPs, at the end of the sludge line usually after thermal drying (Figure 3), are increasing. The advantages in this case consist not only of the minimization of the SS, limiting 
the amount of generated SS exiting the WWTP, but also in the possibility of recovering the energy produced directly inside the WWTP.

\subsubsection{Combustion}

Combustion means the complete oxidative process that occurs at temperatures between $850{ }^{\circ} \mathrm{C}$ and $1000{ }^{\circ} \mathrm{C}$ and in over-stoichiometric conditions of $\mathrm{O}_{2}$. Before subjecting the sludge to a heat treatment, such as combustion (the same concept can then be repeated similarly for pyrolysis and gasification), generally it needs to be subjected to mechanical dewatering and thermal drying: this is in order to have sludge with sufficient calorific value to allow autothermal combustion $[109,110]$. To date, the full-scale applications of this technology are increasing. If the calorific value is not enough, the combustion of the sludge is problematic: in this case, the appropriate choice is co-combustion, outside the WWTP, with materials having a high lower heating value (LHV) $[7,111]$. Therefore, SS can be used as auxiliary fuel in coal-fired power plants and cement kilns $[7,112]$. For some years, co-combustion with other materials has received considerable interest $[7,113,114]$. The most common co-combustion is sludge with solid urban waste. This allows us to use more conventional plant techniques. This type of treatment acts not only on the water content of the sludge but also on the organic substance, which is then oxidized and transformed, finally allowing a considerable reduction in the volume of sludge produced. To date, the full-scale applications of this technology are significant.

\subsubsection{Pyrolysis}

The pyrolysis process realizes the thermal degradation of the fuel in an inert atmosphere (i.e., in the absence of oxidizing agents) between $500{ }^{\circ} \mathrm{C}$ and $1000{ }^{\circ} \mathrm{C}$ and is indicated by the literature as a promising solution [1,112]. In this process, the pyrolyzed material does not undergo combustion, but the structure of the molecules breaks down thanks to the effect of temperature alone [111]. From these thermolytic reactions, three by-products are formed: (i) bituminous coal (solid); (ii) pyrolytic oil (liquid) and (iii) syngas (aeriform). Bituminous coal (char) can then possibly be used as a solid fuel or transformed into activated carbon. Pyrolysis can be aimed at obtaining mainly char, liquid or syngas depending on the operational conditions [112]. There are some advantages associated with this process. For instance, (i) the reduced production of $\mathrm{CO}_{2}$, (ii) the total reduction of dioxins, (iii) the high flexibility, (iv) the compact installation and of course (v) the minimization of the residue is worthy of mention [115].

\subsubsection{Gasification}

Gasification consists of converting the carbon content of sewage sludge into ash and a combustible gas. The process takes place at higher temperatures compared to pyrolysis (typically above $500{ }^{\circ} \mathrm{C}$ ) $[1,111]$. The oxidizing agent is dosed lower than the stoichiometric value compared to the amount of organic carbon (sub-stoichiometric conditions). Oxidation is therefore to be considered partial [111]. In addition to obtaining the removal of water from the sludge and the reduction of the content of volatile substance, there is also the production of a fuel in the gaseous phase (Syngas), which can then be reused for energy production.

In Table 3, several applications of thermal treatments, with literature information, are reported. 
Table 3. Several applications of thermal treatments.

\begin{tabular}{|c|c|c|c|}
\hline Process & Temperature $\left[{ }^{\circ} \mathrm{C}\right]$ & Results & Ref. \\
\hline Combustion & 800 & $\begin{array}{l}\text { The main decomposition during the combustion process is in } \\
\text { the } 180-580^{\circ} \mathrm{C} \text { temperature range. The highest mass loss is } \\
\text { caused mainly by the decomposition of carbohydrates and } \\
\text { lipids. After this process, c.a. } 77 \% \text {, of total mass is degraded. }\end{array}$ & [116] \\
\hline Combustion & n.a. & $\begin{array}{l}\text { High reduction of sludge volume by about } 90 \% \text { and nearly } \\
\text { complete elimination of the organic materials. }\end{array}$ & [110] \\
\hline Pyrolysis & $460-600$ & $\begin{array}{l}\text { In pyrolysis, the second stage finishes at } \sim 540{ }^{\circ} \mathrm{C} \text {, with an } \\
\text { average } 55 \mathrm{wt} . \% \text { mass loss. The final decomposition is of } \\
\text { inorganic matter. }\end{array}$ & [116] \\
\hline Pyrolysis & 300 & $\begin{array}{l}\text { Pyrolysis temperature was the most important factor affecting } \\
\text { the yield of biochars produced. Sewage sludge pyrolysis at } \\
\qquad 300^{\circ} \mathrm{C} \text { maximized biochar yield. }\end{array}$ & [117] \\
\hline Pyrolysis & 500-900 & $\begin{array}{l}\text { Biophysical dried sludge was rapidly pyrolyzed at } \\
\text { temperatures from } 500^{\circ} \mathrm{C} \text { to } 900{ }^{\circ} \mathrm{C} \text {. With the temperature } \\
\text { rising, the yield of biochars decreased, the ash content and } \\
\text { microstructure development of biochars were promoted. }\end{array}$ & [118] \\
\hline Pyrolysis & n.a. & $\begin{array}{l}\text { Volume reduction by as much as } 90 \% \text { and production of a } \\
\text { sterile carbon char high efficiency and energy self-sufficient. }\end{array}$ & [110] \\
\hline $\begin{array}{l}\text { Drying + } \\
\text { Gasification }\end{array}$ & $\begin{array}{c}120 \text { (Drying) } \\
\text { 550-900 (Gasification) }\end{array}$ & $\begin{array}{l}\text { SS was partially dried in an oven at } 120^{\circ} \mathrm{C} \text { for } 2 \mathrm{~h} \text {. The drying } \\
\text { reduced the moisture content from } 43 \% \text { to } 3.5 \% \text {. After } \\
\text { gasification, the moisture content in the char was } 2.1-2.8 \% \text {. }\end{array}$ & [119] \\
\hline
\end{tabular}

\subsection{Electrochemical Treatments}

For minimizing the production of SS, electrochemical treatments are generally coupled with the use of pressure. Among the pressurized electro-dewatering treatments, electro-osmosis is arousing a growing interest [120-122].

\section{Electro-Osmosis}

In this case, the osmosis process is combined with the use of electric current [120]. Gronchi et al. [123] have recently tested this type of treatment. They obtained up to $40-45 \%$ of dry substance content compared to $20-25 \%$ obtainable by conventional physical/mechanical processes [123]. This type of process can be applied in the sludge line, before or after the phase of stabilization, with very low energy consumption: $0.12-0.5 \mathrm{kWh} \mathrm{kg}_{\text {water }}{ }^{-1}$ for activated sludge and $0.14-0.55 \mathrm{kWh} \mathrm{kg}_{\text {water }}{ }^{-1}$ for digested sludge $[124,125]$. Moreover, other advantages, such as the removal of pathogens and reduction of the final transportation cost, can be highlighted [125]. Therefore, the application of an electric field, combined with pressure, tends to increase the dehydration of the sludge. Many experimental factors can influence the reduction of water content and consequently, the process yields: (i) the electric voltage, (ii) the pressure, (iii) the contact time, (iv) the characteristics of the polyelectrolyte dosed, (v) the temperature, etc. The electrode reactions are not only influenced by the material of which the electrode is made but also by the ions contained in the sludge. The process could therefore be hindered by the characteristics of the sludge $[123,126]$, although the action mechanism has not yet been fully clarified [126]. Other experiments confirmed these results, and 38-45\% of dry matter has been obtained [122,127]. In Table 4, some applications and results of electro-dewatering processes are reported. 
Table 4. Several applications of electro-osmosis processes.

\begin{tabular}{ccccccc}
\hline $\begin{array}{c}\text { Initial DM } \\
{[\%]}\end{array}$ & $\begin{array}{c}\text { Final } \\
\text { DM [\%] }\end{array}$ & $\begin{array}{c}\text { Time } \\
{[\mathbf{m i n}]}\end{array}$ & $\begin{array}{c}\text { Pressure } \\
{[\mathbf{k P a}]}\end{array}$ & Voltage [V] & $\begin{array}{c}\text { Energy Consumption } \\
{\left[\mathbf{k W h} \mathbf{~ k g}_{\text {water }} \mathbf{- 1}\right]}\end{array}$ & References \\
\hline 16.6 & 40 & 7.5 & 100 & 20 & 0.065 & {$[121]$} \\
$20-25$ & $40-50$ & $10-14$ & 25.5 & $30-40$ & $0.06-0.18$ & {$[125]$} \\
22 & 37.5 & 30 & n.a. & 15 & n.a. & {$[128]$} \\
& 40 & & & 25 & n.a. & \\
& 46 & & & 35 & n.a. & n.a. \\
n.a. & 40 & 16 & n.a. & 25 & n.a. & {$[129]$} \\
& 45 & & & 35 & 0.123 & {$[122]$} \\
18 & 40 & 25 & 300 & $10-20$ & n.a. & {$[124]$} \\
\hline
\end{tabular}

DM: Dry matter; n.a.: Not available.

\section{Summary}

In the following review, advanced treatments for the minimization of SS production have been analysed. Chemical, biological, thermal and electrochemical processes have been reported (Table 5).

Table 5. Uses and yields of advanced treatments and technology for the minimization of SS and maturity of technology $[7,11,21,25,45,82,83,115,123,130,131]$.

\begin{tabular}{|c|c|c|c|c|c|}
\hline \multirow{2}{*}{\multicolumn{2}{|c|}{ Technique }} & \multicolumn{2}{|c|}{ Use } & \multirow{2}{*}{$\begin{array}{c}\text { Maturity of Technology } \\
\text { [Scale] }\end{array}$} & \multirow{2}{*}{ Effect } \\
\hline & & Water Line & Sludge Line & & \\
\hline \multirow{4}{*}{ Chemical } & $\left(\mathrm{O}_{3}\right)$ & $x$ & $x$ & Real & (B) \\
\hline & WO & & $X$ & Real & (B) $(\mathrm{C})$ \\
\hline & Fenton & $x$ & $x$ & Laboratory & (B) \\
\hline & $\mathrm{TCH}^{(1)}$ & $x$ & $x$ & $\begin{array}{l}\text { Laboratory (in water line) } \\
\quad \text { Real (in sludge line) }\end{array}$ & (B) \\
\hline \multirow{4}{*}{ Biological } & MMBR & $x$ & & Real & (A) \\
\hline & TMBR & $x$ & $x$ & Real & $\begin{array}{l}\text { In the water line (A) } \\
\text { In the sludge line (B) }\end{array}$ \\
\hline & GSS & $x$ & & Real & (A) \\
\hline & BP & $x$ & $x$ & $\begin{array}{c}\text { Real (in water line) } \\
\text { Laboratory (in sludge line) }\end{array}$ & (B) \\
\hline \multirow{3}{*}{ Thermal } & Combustion & & $x$ & Real & (B) (C) \\
\hline & Pyrolysis & & $x$ & Laboratory & (B) (C) \\
\hline & Gasification & & $x$ & Laboratory & (B) (C) \\
\hline Electrochemical & Electro-Osmosis & & $X$ & Laboratory & (C) \\
\hline
\end{tabular}

(A): reduction of the production of sludge in water line; (B) reduction of the fraction of VS; (C) dewatering. (1):

In the sludge line, it must be coupled with anaerobic digestion.

Chemical treatments such as ozonation or the use of chlorine certainly have the advantage of representing a mature technology. However, if adopted in the water line, they can easily alter the balance within the biological sector. WO is one of the most interesting of the advanced chemical processes from the point of view of performance (in terms of sludge reduction). However, it should be remembered that it requires highly qualified personnel for its management. The Fenton and Photo-Fenton processes are still applied to the pilot scale only. The great disadvantage is that chemical sludge is inevitably produced, which must then be properly disposed of. $\mathrm{TCH}$ is currently adopted at the real scale, as pre-treatment before the anaerobic digestion in the sludge line, in order to maximize the stabilization of the SS. One of the main disadvantages is due to the cost for chemical reagents for enhancing the hydrolysis pre-treatment.

Among the biological processes, interesting results are given, for example, by the application of the MMBRs in the water line that allow a significant reduction of the sludge produced compared to the CAS. For these systems, which are already widely adopted at the real scale, fouling remains the main problem. On the other hand, despite having shown significant results, especially if applied in the sludge line, the 
TMBRs do not yet have a high diffusion. Finally, among the advanced biological processes, the BP is presented. This has given interesting results in terms of minimization yields of SS but nevertheless there are not yet a significant number of applications at the real scale (mostly examples exist on a pilot scale).

The research has shown increasing interest in recent years for thermal processes. Combustion treatments are widely applied to the real scale, while pyrolysis and gasification present more difficulty in plant engineering and are currently applied only to the pilot scale.

Among the electrochemical dewatering processes, electro-osmosis is the most significant. It does not present a considerable number of applications to real plants; however, it allows an important reduction of the water content in SS. Given that in recent years the research has allowed us to optimize energy consumption, the first important disadvantage of this process, a considerable development of this type of treatment in the coming years can be expected.

Therefore, in order to minimize the production of SS, there is not a best solution for every situation, but the optimal treatments and technologies must be evaluated on a case-by-case basis. For having a complete and objective evaluation, a comparative analysis of different applicable solutions should be carried out as reported in different works [132-134].

Moreover, by way of example, a list of several patents available on the market is shown (Table 6). The presence of other patents not mentioned in the table is not excluded.

Table 6. List of several patents, by way of example, available on the market. The presence of other patents not mentioned here is not excluded.

\begin{tabular}{|c|c|c|c|}
\hline \multicolumn{2}{|c|}{ Process } & \multirow{2}{*}{ Patent Name } & \multirow{2}{*}{ Description } \\
\hline Type & Name & & \\
\hline \multirow{9}{*}{ Chemical processes } & $\mathrm{O}_{3}$ & Biolysis- $\mathrm{O}^{\circledR}$ & $\begin{array}{l}\text { In this technology, the mixed liquor extracted from the CAS reactor } \\
\text { is in contact with ozone into another reactor and returned to the } \\
\text { CAS tank. }\end{array}$ \\
\hline & WO & $\mathrm{TOP}^{\circledR}$ & $\begin{array}{l}\text { Suitable for mixtures consisting of at least two phases, one dense } \\
\text { (SS) and one liquid (WW). The solid residue that leaves the plant } \\
\text { can be recovered by conventional decantation and filtration. } \\
\text { This can be converted into a primary-secondary material. } \\
\text { This material obtained the CE mark as a filler according to UNI EN } \\
13043 \text {. }\end{array}$ \\
\hline & WO & DUAL TOP ${ }^{\circledR}$ & $\begin{array}{l}\text { The technology can simultaneously process: (i) activated sludge } \\
\text { derived from industrial or municipal biological plants, (ii) } \\
\text { industrial wastewater, (iii) landfill leachates with high levels of } \\
\text { COD and (iv) highly contaminated sediments (marine, fluvial, etc.). }\end{array}$ \\
\hline & WO & Athos ${ }^{\circledR}$ & $\begin{array}{l}\text { It is a solution based on the principle of } \mathrm{WO} \text {, but which operates at } \\
\text { more moderate temperatures }\left(240^{\circ} \mathrm{C}\right) \text { and lower pressures }(45 \mathrm{bar}) \text {. } \\
\text { It is a compact process that performs almost complete oxidation of } \\
\text { the organic matter with a minimum retention time of the sludge } \\
\text { (less than } 1 \mathrm{~h}) \text {. }\end{array}$ \\
\hline & WO & Zimpro $^{\circledR}$ & $\begin{array}{l}\text { Most of these systems are low-temperature and low-pressure } \\
\text { designs, commonly referred to as low pressure oxidation. These } \\
\text { systems use temperatures and pressures of less than } 220^{\circ} \mathrm{C} \text { and } 35 \\
\text { bar, respectively. }\end{array}$ \\
\hline & $\mathrm{TCH}$ & Cambi THP ${ }^{\circledR}$ & $\begin{array}{l}\text { Without the use of chemical reagents, it improves both digestion } \\
\text { and dewaterability after digestion with up to } 45 \% \text { DM. The mass } \\
\text { reduction is around } 40-70 \% \text {. }\end{array}$ \\
\hline & $\mathrm{TCH}$ & $\mathrm{HCHS}^{\circledR}$ & $\begin{array}{l}\text { It allows us to obtain up to } 22 \% \text { dehydration by operating with } \\
\text { saturated steam at } 6 \text { bar at a temperature between } 150 \text { and } 170{ }^{\circ} \mathrm{C} \text {. }\end{array}$ \\
\hline & $\mathrm{TCH}$ & TurboTec $^{\circledR}$ & $\begin{array}{l}\text { Before entering the system, the raw biomass is screened. After } \\
\text { being sieved, the biomass is partially heated using the heat of the } \\
\text { outgoing biomass. The temperature is increased by using steam at } \\
140-160^{\circ} \mathrm{C} \text { introduced into the reactor. The reactor is a continuous } \\
\text { mixing system (CSRT). Following hydrolysis, the biomass is cooled } \\
\text { through contact with heat exchangers. }\end{array}$ \\
\hline & $\mathrm{TCH}$ & Bio Thelys ${ }^{\circledR}$ & $\begin{array}{l}\text { Without the use of chemical reagents and coupled with anaerobic } \\
\text { digestion, it offers better performance than conventional digestion } \\
\text { and optimizes sludge treatment by producing: (i) }-25-35 \% \text { DM } \\
\text { and (ii) }+30-50 \% \text { biogas. }\end{array}$ \\
\hline
\end{tabular}


Table 6. Cont.

\begin{tabular}{|c|c|c|c|}
\hline \multicolumn{2}{|c|}{ Process } & \multirow{2}{*}{ Patent Name } & \multirow{2}{*}{ Description } \\
\hline Type & Name & & \\
\hline \multirow{2}{*}{ Biological } & TMBR & Biorime ${ }^{\circledR}$ & $\begin{array}{l}\text { Biorime consists of a Thermophilic Aerobic Membrane Reactor } \\
\text { (TAMR). TAMR works at temperatures around } 54^{\circ} \mathrm{C} \text {. Pure oxygen } \\
\text { is insufflated inside the reactor. }\end{array}$ \\
\hline & $\mathrm{BP}$ & Cannibal $^{\circledR}$ & $\begin{array}{l}\text { It allows a reduction in secondary sludge production. } \\
\text { The technology is applicable both to new plants and to up-grade } \\
\text { existing plants. The technology is based on the retention of a part } \\
\text { of recirculating sludge in a tank subject to micro-aeration. }\end{array}$ \\
\hline \multirow[t]{2}{*}{ Thermal } & Combustion & HELIOSOLIDS ${ }^{\circledR}$ & $\begin{array}{l}\text { It can be applied to: (i) municipal and industrial SS, (ii) oily sludge } \\
\text { and slurry, (iii) spent grains, (iv) paint and paint sludge, (v) } \\
\text { shredded wood and pellets, (vi) meat and bone meal, (vii) acid oils } \\
\text { and (viii) soap stock. }\end{array}$ \\
\hline & Pyrolysis & PyroBoiler ${ }^{\circledR}$ & $\begin{array}{l}\text { By combining the pyrolysis treatment with the drying treatment, it } \\
\text { allows a reduction in the output flow up to } 80 \% \text { in weight and } 60 \% \\
\text { in volume. }\end{array}$ \\
\hline
\end{tabular}

DM: Dry matter; WW: Wastewater; COD: Chemical oxygen demand.

\section{Discussion}

The proposed treatments (Table 5) lead to a reduction in sludge production, not only in agricultural but also in urban and industrial areas. Assuming the application of proposed processes, for example, on the urban WWTPs with a capacity higher than 100,000 population equivalent (PE), this would cover more than $50 \%$ of the total load (expressed in PE) treated in EU28 [135]. In Table 7, the SS disposal options and costs in Europe are reported.

Table 7. Sewage sludge (SS) disposal options and costs in Europe.

\begin{tabular}{|c|c|c|c|}
\hline \multirow{2}{*}{ Type of Disposal } & \multirow{2}{*}{ SS Disposal [\%] ${ }^{(a)}$} & \multicolumn{2}{|c|}{ Disposal Costs $\left[€ \mathrm{Mg}_{\mathrm{DM}}{ }^{-1}\right]^{(\mathrm{b})}$} \\
\hline & & $\min$ & $\max$ \\
\hline Agriculture & 28.3 & 150 & 400 \\
\hline Compost & 14.8 & 250 & 600 \\
\hline Incineration & 37.7 & 450 & 800 \\
\hline Landfill & 7.1 & 200 & 600 \\
\hline Other & 12.1 & 90 & 260 \\
\hline Transport & 100 & 50 & 160 \\
\hline
\end{tabular}

(a): [14]; (b): [25,136].

As reported by Foladori et al. [25], the transport is indicated as $100 \%$ because all the disposal options require the SS transport from the WWTP where it is produced. Currently in Europe, about 9.7 million $\mathrm{Mg}_{\mathrm{DM}}$ year ${ }^{-1}$ of SS are produced [14]. As previously reported (e.g., Sections 3.1 and 3.2), interventions in the wastewater line present greater risks of the balance alteration in the biological reactor (i.e., CAS) and partial inhibition of biomass. Considering minimization technologies only in the sludge line, a precautionary minimization yield of $50 \%$ can be assumed. Therefore, by adopting these criteria only in the WWTPs with over 100,000 PE (i.e., about $50 \%$ of the total SS produced in Europe) makes it possible to reduce the SS produced each year to around 7.28 million $\mathrm{Mg}_{\mathrm{DM}}$ year ${ }^{-1}$. This would significantly reduce the costs related to the different disposal options currently adopted in Europe, as shown in Figure 5. 


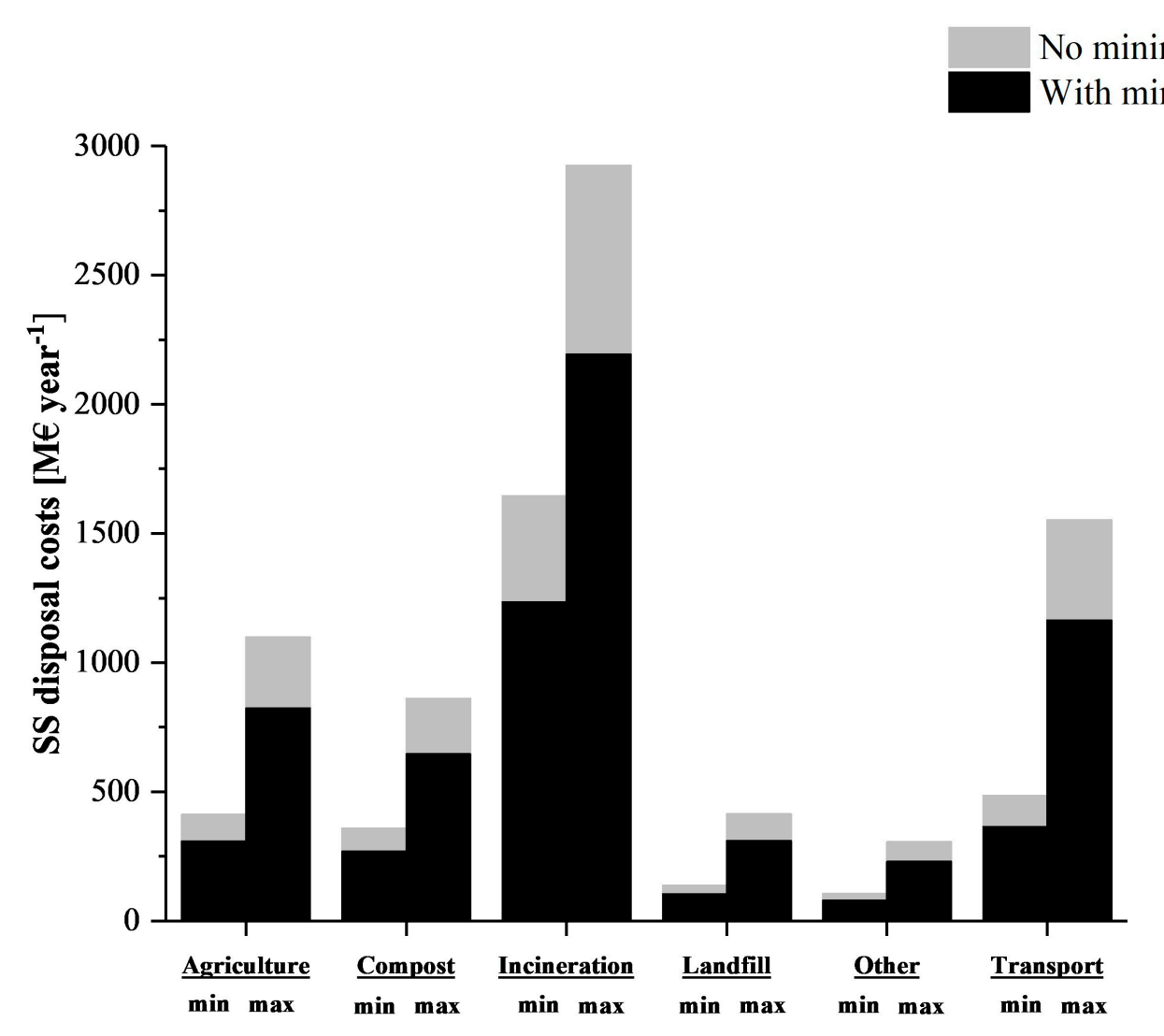

Figure 5. Comparison between the total costs of the different SS disposal options in Europe in 2015, before and after the hypothetical application of minimization techniques in the plants with more than 100,000 PE. A range of SS disposal costs, between a minimum and maximum value, was determined considering the high variability within the different EU countries.

Furthermore, as reported by Kalderis et al. [136], costs vary. Minimizing the production of SS has the disadvantage of the costs of implementing the WWTPs (not subject to analysis here) but it would allow reducing the costs of disposal of the SS and would eliminate the variable given by the SS disposal price fluctuation.

\section{Conclusions}

This paper presents a review of the various treatments applicable for the minimization of SS. Only advanced technologies and treatments are reported. This work is based on about 130 papers, reviews, books and conference proceedings. A description of the process, the advantages, the drawbacks and the results of the literature are presented for each type of technology. Both the interventions on the sludge line and those on the water line are shown. In order to minimize the SS production, the results of the bibliometric analysis show the increased interest in the combination of different types of treatments and technologies and the reduction of the study of treatments exclusively of a chemical nature. Among the biological treatments, while MMBR and TMBR allow us to obtain encouraging results, the BP must be studied even before possible intensive application at a real scale. In order to minimize the SS, thermal treatments have gained interest in recent years. However, while combustion and co-combustion of SS are already applied at the real scale, pyrolysis and gasification are currently under study and development. Finally, electro-osmosis is arousing a growing interest. The results are encouraging, but the maturity of the technology is not yet developed, and other studies are needed before a real-scale application. Assuming the application of proposed processes in the sludge line in WWTPs with a capacity higher than 100,000 PE, this would significantly reduce the costs related to the different disposal options currently adopted in Europe. 
Author Contributions: M.C.M. contributed to the drafting of the sections related to the different available advanced processes. A.A. contributed to the drafting of the summary and discussion (Sections 4 and 5). M.C.C. and V.T. supervised the study and the paper drafting. All authors have read and approved the final manuscript.

Funding: This research received no external funding.

Acknowledgments: The authors are grateful to Pavia Acque S.c.a.r.l., ASMia s.r.l. (ASM Mortara S.p.a. Group) and ASM Pavia S.p.a. for providing technical assistance.

Conflicts of Interest: The authors declare no conflict of interest.

\section{Nomenclature}

$\begin{array}{ll}\text { AeGSS } & \text { Aerobic granular sludge systems } \\ \text { AnGSS } & \text { Anaerobic granular sludge systems } \\ \text { AOP } & \text { Advanced oxidation process } \\ \text { BP } & \text { Biological predation } \\ \text { CAS } & \text { Conventional activate sludge } \\ \text { COD } & \text { Chemical oxygen demand } \\ \text { DM } & \text { Dry matter } \\ \text { DOC } & \text { Dissolved oxygen carbon } \\ \text { GSS } & \text { Granular sludge systems } \\ \text { HRT } & \text { Hydraulic retention time } \\ \text { MBR } & \text { Membrane biological reactor } \\ \text { MLSS } & \text { Mixed liquor suspended solids } \\ \text { MMBR } & \text { Mesophilic membrane bioreactor } \\ \text { SBBGR } & \text { Sequencing batch biofilter granular reactor } \\ \text { SBR } & \text { Sequencing batch reactor } \\ \text { SRR } & \text { Sludge reduction ratio } \\ \text { SRT } & \text { Sludge retention time } \\ \text { SS } & \text { Sewage sludge } \\ \text { SSR } & \text { Sludge solubilization rate } \\ \text { TCH } & \text { Thermochemical hydrolysis } \\ \text { TKN } & \text { Total kjeldahl nitrogen } \\ \text { TMBR } & \text { Thermophilic membrane bioreactor } \\ \text { TS } & \text { Total solids } \\ \text { TSS } & \text { Total suspended solids } \\ \text { VFAs } & \text { Volatile fatty acids } \\ \text { VS } & \text { Volatile solids } \\ \text { VSS } & \text { Volatile suspended solids } \\ \text { WO } & \text { Wet oxidation } \\ \text { WW } & \text { Wastewater } \\ \text { WWTP } & \text { Wastewater treatment plant } \\ & \end{array}$

\section{References}

1. Bianchini, A.; Bonfiglioli, L.; Pellegrini, M.; Saccani, C. Sewage sludge drying process integration with a waste-to-energy power plant. Waste Manag. 2015, 42, 159-165. [CrossRef] [PubMed]

2. Gherghel, A.; Teodosiu, C.; De Gisi, S. A review on wastewater sludge valorisation and its challenges in the context of circular economy. J. Clean. Prod. 2019, 228, 244-263. [CrossRef]

3. Kelessidis, A.; Stasinakis, A.S. Comparative study of the methods used for treatment and final disposal of sewage sludge in European countries. Waste Manag. 2012, 32, 1186-1195. [CrossRef] [PubMed]

4. Bertanza, G.; Papa, M.; Canato, M.; Collivignarelli, M.C.; Pedrazzani, R. How can sludge dewatering devices be assessed? Development of a new DSS and its application to real case studies. J. Environ. Manag. 2014, 137, 86-92. [CrossRef] [PubMed]

5. Shehu, M.S.; Abdul Manan, Z.; Wan Alwi, S.R. Optimization of thermo-alkaline disintegration of sewage sludge for enhanced biogas yield. Bioresour. Technol. 2012, 114, 69-74. [CrossRef] [PubMed] 
6. Pérez-Elvira, S.I.; Nieto Diez, P.; Fdz-Polanco, F. Sludge minimisation technologies. Rev. Environ. Sci. Bio/Technol. 2006, 5, 375-398. [CrossRef]

7. Sever Akdağ, A.; Atak, O.; Atimtay, A.T.; Sanin, F.D. Co-combustion of sewage sludge from different treatment processes and a lignite coal in a laboratory scale combustor. Energy 2018, 158, 417-426. [CrossRef]

8. Directive 2018/851 of the European Parliament and of the Council of 30 May 2018 amending Directive 2008/98/EC on Waste; European Parliament and Council of the European Union: Bruxelles, Belgium, 2018.

9. Collivignarelli, M.C.; Abbà, A.; Padovani, S.; Frascarolo, M.; Sciunnach, D.; Turconi, M.; Orlando, M. Recovery of sewage sludge on agricultural land in Lombardy: current issues and regulatory scenarios. Environ. Eng. Manag. J. 2015, 14, 1477-1486. [CrossRef]

10. Bertanza, G.; Canato, M.; Laera, G.; Tomei, M.C. Methodology for technical and economic assessment of advanced routes for sludge processing and disposal. Environ. Sci. Pollut. Res. 2015, 22, 7190-7202. [CrossRef]

11. Collivignarelli, M.C.; Castagnola, F.; Sordi, M.; Bertanza, G. Treatment of sewage sludge in a thermophilic membrane reactor (TMR) with alternate aeration cycles. J. Environ. Manag. 2015, 162, 132-138. [CrossRef]

12. Torretta, V. Environmental and economic aspects of water kiosks: Case study of a medium-sized Italian town. Waste Manag. 2013, 33, 1057-1063. [CrossRef] [PubMed]

13. Sorlini, S.; Collivignarelli, M.C.; Castagnola, F.; Crotti, B.M.; Raboni, M. Methodological approach for the optimization of drinking water treatment plants' operation: A case study. Water Sci. Technol. 2015, 71, 597-604. [CrossRef] [PubMed]

14. Eurostat Sewage Sludge Production and Disposal. European Statistical Office: Luxembourg, 2019. Available online: https://ec.europa.eu/eurostat/web/products-datasets/-/env_ww_spd (accessed on 20 June 2019).

15. EC. Environmental, Economic and Social Impacts of the Use of Sewage Sludge on Land | Part II: Report on Options and Impacts. European Commission, 2010. Available online: http://ec.europa.eu/environment/ archives/waste/sludge/pdf/part_ii_report.pdf (accessed on 20 June 2019).

16. Collivignarelli, M.C.; Abbà, A.; Bestetti, M.; Crotti, B.M.; Carnevale Miino, M. Electrolytic Recovery of Nickel and Copper from Acid Pickling Solutions Used to Treat Metal Surfaces. Water. Air Soil. Pollut. 2019, 230, 101. [CrossRef]

17. Fazelipour, M.; Takdastan, A.; Jou, M.S.S. Survey on chlorine application in sequencing batch reactor waste sludge in order to sludge minimization. Asian J. Chem. 2011, 23, 2994-2998.

18. Luciano, A.; Viotti, P.; Mancini, G.; Torretta, V. An integrated wastewater treatment system using a BAS reactor with biomass attached to tubolar supports. J. Environ. Manag. 2012, 113, 51-60. [CrossRef] [PubMed]

19. Richardson, E.E.; Hanson, A.T. Regression Modeling of Ozonation Process in Wastewater Treatment Plants for Reduction of Waste Activated Sludge. Ozone Sci. Eng. 2014, 36, 451-464. [CrossRef]

20. Viotti, P.; Luciano, A.; Mancini, G.; Torretta, V. A wastewater treatment using a biofilm airlift suspension reactor with biomass attached to supports: A numerical model. Int. J. Environ. Sci. Technol. 2014, 11, 571-588. [CrossRef]

21. Wang, Q.; Wei, W.; Gong, Y.; Yu, Q.; Li, Q.; Sun, J.; Yuan, Z. Technologies for reducing sludge production in wastewater treatment plants: State of the art. Sci. Total Environ. 2017, 587-588, 510-521. [CrossRef]

22. Torregrossa, M.; Di Bella, G.; Di Trapani, D. Comparison between ozonation and the OSA process: Analysis of excess sludge reduction and biomass activity in two different pilot plants. Water Sci. Technol. 2012, 66, 185-192. [CrossRef]

23. Tyagi, V.K.; Lo, S.-L. Application of physico-chemical pretreatment methods to enhance the sludge disintegration and subsequent anaerobic digestion: An up to date review. Rev. Environ. Sci. Bio/Technol. 2011, 10, 215-242. [CrossRef]

24. Kamiya, T.; Hirotsuji, J. New combined system of biological process and intermittent ozonation for advanced wastewater treatment. Water Sci. Technol. 1998, 38, 147-153. [CrossRef]

25. Foladori, P.; Andreottola, G.; Ziglio, G. Sludge Reduction Technologies in Wastewater Treatment Plants; IWA Publishing: London, UK, 2010.

26. Gardoni, D.; Ficara, E.; Vergine, P.; Canziani, R. A full-scale plug-flow reactor for biological sludge ozonation. Water Sci. Technol. 2015, 71, 560-565. [CrossRef] [PubMed]

27. Andrews, J.; Dare, P.; Estcourt, G.; Gapes, D.; Lei, R.; McDonald, B.; Wijaya, N. Acetic acid recovery from a hybrid biological-hydrothermal treatment process of sewage sludge-A pilot plant study. Water Sci. Technol. 2015, 71, 734-739. [CrossRef] [PubMed] 
28. Baroutian, S.; Smit, A.-M.; Andrews, J.; Young, B.; Gapes, D. Hydrothermal degradation of organic matter in municipal sludge using non-catalytic wet oxidation. Chem. Eng. J. 2015, 260, 846-854. [CrossRef]

29. Baroutian, S.; Smit, A.-M.; Gapes, D.J. Relative influence of process variables during non-catalytic wet oxidation of municipal sludge. Bioresour. Technol. 2013, 148, 605-610. [CrossRef]

30. Bertanza, G.; Galessi, R.; Menoni, L.; Salvetti, R.; Slavik, E.; Zanaboni, S. Wet oxidation of sewage sludge: full-scale experience and process modeling. Environ. Sci. Pollut. Res. 2015, 22, 7306-7316. [CrossRef] [PubMed]

31. Lombardi, L.; Nocita, C.; Bettazzi, E.; Fibbi, D.; Carnevale, E. Environmental comparison of alternative treatments for sewage sludge: An Italian case study. Waste Manag. 2017, 69, 365-376. [CrossRef]

32. Torretta, V.; Ragazzi, M.; Trulli, E.; De Feo, G.; Urbini, G.; Raboni, M.; Rada, E.C. Assessment of biological kinetics in a conventional municipal WWTP by means of the oxygen uptake rate method. Sustainability 2014, 6, 1833-1847. [CrossRef]

33. Liu, C.; Zhang, P.; Zeng, C.; Zeng, G.; Xu, G.; Huang, Y. Feasibility of bioleaching combined with Fenton oxidation to improve sewage sludge dewaterability. J. Environ. Sci. 2015, 28, 37-42. [CrossRef]

34. Atay, Ş.; Akbal, F. Classification and Effects of Sludge Disintegration Technologies Integrated Into Sludge Handling Units: An Overview. Clean Soil Air Water 2016, 44, 1198-1213. [CrossRef]

35. Şahinkaya, S.; Kalıpcı, E.; Aras, S. Disintegration of waste activated sludge by different applications of Fenton process. Process Saf. Environ. Prot. 2015, 93, 274-281. [CrossRef]

36. Tokumura, M.; Sekine, M.; Yoshinari, M.; Znad, H.T.; Kawase, Y. Photo-Fenton process for excess sludge disintegration. Process Biochem. 2007, 42, 627-633. [CrossRef]

37. Yildiz, S.; Cömert, A. Fenton process effect on sludge disintegration. Int. J. Environ. Health Res. 2019, 1-16. [CrossRef] [PubMed]

38. Anjum, M.; Al-Makishah, N.H.; Barakat, M.A. Wastewater sludge stabilization using pre-treatment methods. Process Saf. Environ. Prot. 2016, 102, 615-632. [CrossRef]

39. Kaynak, G.E.; Filibelt, A. Assessment of fenton process as a minimization technique for biological sludge: Effects on anaerobic sludge bioprocessing. J. Residuals Sci. Technol. 2008, 5, 151-160.

40. He, M.; Wei, C. Performance of membrane bioreactor (MBR) system with sludge Fenton oxidation process for minimization of excess sludge production. J. Hazard. Mater. 2010, 176, 597-601. [CrossRef] [PubMed]

41. Tokumura, M.; Katoh, H.; Katoh, T.; Znad, H.T.; Kawase, Y. Solubilization of excess sludge in activated sludge process using the solar photo-Fenton reaction. J. Hazard Mater. 2009, 162, 1390-1396. [CrossRef]

42. Amudha, V.; Kavitha, S.; Fernandez, C.; Adishkumar, S.; Banu, J.R. Effect of deflocculation on the efficiency of sludge reduction by Fenton process. Environ. Sci. Pollut. Res. 2016, 23, 19281-19291. [CrossRef] [PubMed]

43. Collivignarelli, M.C.; Abbà, A.; Carnevale Miino, M.; Damiani, S. Treatments for color removal from wastewater: State of the art. J. Environ. Manag. 2019, 236, 727-745. [CrossRef]

44. Heng, G.C.; Isa, M.H.; Lim, J.-W.; Ho, Y.-C.; Zinatizadeh, A.A. Enhancement of anaerobic digestibility of waste activated sludge using photo-Fenton pretreatment. Environ. Sci. Pollut. Res. 2017, 24, 27113-27124. [CrossRef]

45. Yu, L.; Zhang, W.; Liu, H.; Wang, G.; Liu, H. Evaluation of volatile fatty acids production and dewaterability of waste activated sludge with different thermo-chemical pretreatments. Int. Biodeterior. Biodegradation. 2018, 129, 170-178. [CrossRef]

46. Park, C.; Lee, C.; Kim, S.; Chen, Y.; Chase, H.A. Upgrading of anaerobic digestion by incorporating two different hydrolysis processes. J. Biosci. Bioeng. 2005, 100, 164-167. [CrossRef] [PubMed]

47. Xie, M.; Wang, C.; Liu, X.; Xiong, R.; Xu, Y. Characteristics of Biochemical and Fractal Structure of Activated Sludge with Thermochemical Lysis. Water Air Soil Pollut. 2017, 228, 187. [CrossRef]

48. Li, Z.; Arnot, M.; Hughes, J.; Yoshida, H.; Tan, P.; Stenstrom, M.K. Reducing Viscosity of Thickened Waste Activated Sludge, Improving Dewaterability of Digested Sludge, and Increasing Biogas Production through Thermochemical Hydrolysis Process. Proc. Water Environ. Fed. 2017, 2017, 5062-5069. [CrossRef]

49. Yang, M.; Sun, Y.; Han, Z.; Liu, J. Exploration on the technology for ozone reduction in urban sewage treatment. IOP Conf. Ser. Earth Environ. Sci. 2017, 64, 012073. [CrossRef]

50. Fall, C.; Silva-Hernández, B.C.; Hooijmans, C.M.; Lopez-Vazquez, C.M.; Esparza-Soto, M.; Lucero-Chávez, M.; van Loosdrecht, M.C.M. Sludge reduction by ozone: Insights and modeling of the dose-response effects. J. Environ. Manag. 2018, 216, 103-112. [CrossRef] 
51. Weiyi, L.; Hong, P.; Yahao, C.; Hong, X. Effect of direct addition of chlorine dioxide into a SBR on its sludge reduction and pollutant removal performance. Chin. J. Environ. Eng. 2016, 6, 39.

52. Menoni, L.; Bertanza, G. Wet Oxidation of sewage sludge: A mathematical model for estimating the performance based on the VSS/TSS ratio. Chem. Eng. J. 2016, 306, 685-692. [CrossRef]

53. Weiner, B.; Breulmann, M.; Wedwitschka, H.; Fühner, C.; Kopinke, F.-D. Wet Oxidation of Process Waters from the Hydrothermal Carbonization of Sewage Sludge. Chem. Ing. Tech. 2018, 90, 872-880. [CrossRef]

54. Malhotra, M.; Garg, A. Performance of non-catalytic thermal hydrolysis and wet oxidation for sewage sludge degradation under moderate operating conditions. J. Environ. Manag. 2019, 238, 72-83. [CrossRef]

55. Munir, M.T.; Mansouri, S.S.; Udugama, I.A.; Baroutian, S.; Gernaey, K.V.; Young, B.R. Resource recovery from organic solid waste using hydrothermal processing: Opportunities and challenges. Renew. Sustain. Energy Rev. 2018, 96, 64-75. [CrossRef]

56. Kavitha, S.; Karthika, P.; Banu, J.R.; Yeom, I.T.; Kumar, S.A. Enhancement of waste activated sludge reduction potential by amalgamated solar photo-Fenton treatment. Desalin. Water Treat. 2016, 57, 13144-13156. [CrossRef]

57. Sharmila, V.G.; Kumar, S.A.; Banu, J.R.; Yeom, I.T.; Saratale, G.D. Feasibility analysis of homogenizer coupled solar photo Fenton process for waste activated sludge reduction. J. Environ. Manag. 2019, 238, 251-256. [CrossRef] [PubMed]

58. Abelleira-Pereira, J.M.; Pérez-Elvira, S.I.; Sánchez-Oneto, J.; de la Cruz, R.; Portela, J.R.; Nebot, E. Enhancement of methane production in mesophilic anaerobic digestion of secondary sewage sludge by advanced thermal hydrolysis pretreatment. Water Res. 2015, 71, 330-340. [CrossRef] [PubMed]

59. Christensen, M.L.; Keiding, K.; Nielsen, P.H.; Jørgensen, M.K. Dewatering in biological wastewater treatment: A review. Water Res. 2015, 82, 14-24. [CrossRef] [PubMed]

60. Torretta, V.; Urbini, G.; Raboni, M.; Copelli, S.; Viotti, P.; Luciano, A.; Mancini, G. Effect of powdered activated carbon to reduce fouling in membrane bioreactors: A sustainable solution. Case study. Sustainability 2013, 5, 1501-1509. [CrossRef]

61. Capodici, M.; Mannina, G.; Torregrossa, M. Waste activated sludge dewaterability: comparative evaluation of sludge derived from CAS and MBR systems. Desalin. Water Treat. 2016, 57, 22917-22925. [CrossRef]

62. Pontoni, L.; Fabbricino, M.; Frunzo, L.; Pirozzi, F.; Esposito, G. Biological stability and dewaterability of CAS and MBR sludge. Desalin. Water Treat. 2016, 57, 22926-22933. [CrossRef]

63. De Oliveira, T.S.; Corsino, S.F.; Di Trapani, D.; Torregrossa, M.; Viviani, G. Biological minimization of excess sludge in a membrane bioreactor: Effect of plant configuration on sludge production, nutrient removal efficiency and membrane fouling tendency. Bioresour. Technol. 2018, 259, 146-155. [CrossRef]

64. Santos, I.C.; Hildenbrand, Z.L.; Schug, K.A. Mass Spectrometry for the Study of Microbial Communities in Environmental Waters. In Advances in Chemical Pollution, Environmental Management and Protection; Elsevier Inc.: Amsterdam, The Netherlands, 2017; Volume 1, pp. 353-380.

65. Iorhemen, O.; Hamza, R.; Tay, J. Membrane Bioreactor (MBR) Technology for Wastewater Treatment and Reclamation: Membrane Fouling. Membranes (Basel) 2016, 6, 33. [CrossRef]

66. Tee, P.F.; Abdullah, M.O.; Tan, I.A.W.; Rashid, N.K.A.; Amin, M.A.M.; Nolasco-Hipolito, C.; Bujang, K. Review on hybrid energy systems for wastewater treatment and bio-energy production. Renew. Sustain. Energy Rev. 2016, 54, 235-246. [CrossRef]

67. Yamashita, K.; Itokawa, H.; Hashimoto, T. Demonstration of energy-saving membrane bioreactor (MBR) systems. Water Sci. Technol. 2019. [CrossRef] [PubMed]

68. Laurinonyte, J.; Meulepas, R.J.W.; van den Brink, P.; Temmink, H. Membrane Bioreactor (MBR) as Alternative to a Conventional Activated Sludge System Followed by Ultrafiltration (CAS-UF) for the Treatment of Fischer-Tropsch Reaction Water from Gas-to-Liquids Industries. Water Air Soil Pollut. 2017, 228, 137. [CrossRef]

69. Collivignarelli, M.C.; Abbà, A.; Benigna, I.; Sorlini, S.; Torretta, V. Overview of the main disinfection processes for wastewater and drinking water treatment plants. Sustainability 2017, 10, 86. [CrossRef]

70. Pontoni, L.; Papirio, S.; D’Alessandro, G.; Caniani, D.; Gori, R.; Mannina, G.; Capodici, M.; Nicosia, S.; Fabbricino, M.; Pirozzi, F.; et al. Dewaterability of CAS and MBR Sludge: Effect of Biological Stability and EPS Composition. J. Environ. Eng. 2018, 144, 04017088. [CrossRef] 
71. Capodici, M.; Mannina, G. The sludge dewaterability in membrane bioreactors. In Proceedings of the SIDISA: X International Symposium on Sanitary and Environmental Engineering, Rome, Italy, 19-23 June 2016; pp. 1-14, Session E01: Treatment of wastewater sludge.

72. Pontoni, L.; D'Alessandro, G.; D’Antonio, G.; Esposito, G.; Fabbricino, M.; Frunzo, L.; Pirozzi, F. Effect of Anaerobic Digestion on Rheological Parameters and Dewaterability of Aerobic Sludges from MBR and Conventional Activated Sludge Plants. Chem. Eng. Trans. 2015, 43, 2311-2316. [CrossRef]

73. Laera, G.; Pollice, A.; Saturno, D.; Giordano, C.; Lopez, A. Zero net growth in a membrane bioreactor with complete sludge retention. Water Res. 2005, 39, 5241-5249. [CrossRef]

74. Pollice, A.; Laera, G.; Saturno, D.; Giordano, C. Effects of sludge retention time on the performance of a membrane bioreactor treating municipal sewage. J. Memb. Sci. 2008, 317, 65-70. [CrossRef]

75. He, S.; Xue, G.; Wang, B. Activated sludge ozonation to reduce sludge production in membrane bioreactor (MBR). J. Hazard Mater. 2006, 135, 406-411. [CrossRef] [PubMed]

76. Zheng, Y.; Cheng, C.; Zhou, Z.; Pang, H.; Chen, L.; Jiang, L.-M. Insight into the roles of packing carriers and ultrasonication in anaerobic side-stream reactor coupled membrane bioreactors: Sludge reduction performance and mechanism. Water Res. 2019, 155, 310-319. [CrossRef]

77. Ji, S.-Q.; Meng, D.-D.; Zhang, K.-D.; Li, F.-L. Diversity of Thermophilic Microorganisms and Their Roles in Carbon Cycle. In Thermophilic microorganisms; Li, F.-L., Ed.; Caister Academic Press: Norfolk, UK, 2015; pp. 13-46. [CrossRef]

78. Duncan, J.; Bokhary, A.; Fatehi, P.; Kong, F.; Lin, H.; Liao, B. Thermophilic membrane bioreactors: A review. Bioresour. Technol. 2017, 243, 1180-1193. [CrossRef] [PubMed]

79. Beaudet, R.; Gagnon, C.; Bisaillon, J.G.; Ishaque, M. Microbiological aspects of aerobic thermophilic treatment of swine waste. Appl. Environ. Microbiol. 1990, 56, 971-976. [PubMed]

80. Cramer, M.; Kloth, S.; Tränckner, J. Optimization and fouling mechanism of a thermophile submerged MBR (TSMBR) pilot plant for wastewater treatment in a paper mill. J. Water Process Eng. 2017, 17, 110-116. [CrossRef]

81. Collivignarelli, M.C.; Castagnola, F.; Sordi, M.; Bertanza, G. Sewage sludge treatment in a thermophilic membrane reactor (TMR): factors affecting foam formation. Environ. Sci. Pollut. Res. 2017, 24, 2316-2325. [CrossRef] [PubMed]

82. Collivignarelli, M.C.; Abbà, A.; Bertanza, G.; Barbieri, G. Treatment of high strength aqueous wastes in a thermophilic aerobic membrane reactor (TAMR): performance and resilience. Water Sci. Technol. 2017, 76, 3236-3245. [CrossRef]

83. Collivignarelli, M.C.; Abbà, A.; Bertanza, G. Why use a thermophilic aerobic membrane reactor for the treatment of industrial wastewater/liquid waste? Environ. Technol. 2015, 36, 2115-2124. [CrossRef]

84. Long, B.; Xuan, X.; Yang, C.; Zhang, L.; Cheng, Y.; Wang, J. Stability of aerobic granular sludge in a pilot scale sequencing batch reactor enhanced by granular particle size control. Chemosphere 2019, 225, 460-469. [CrossRef] [PubMed]

85. Szabó, E.; Liébana, R.; Hermansson, M.; Modin, O.; Persson, F.; Wilén, B.-M. Microbial Population Dynamics and Ecosystem Functions of Anoxic/Aerobic Granular Sludge in Sequencing Batch Reactors Operated at Different Organic Loading Rates. Front Microbiol. 2017, 8. [CrossRef]

86. De Vleeschauwer, F.; Caluwé, M.; Dobbeleers, T.; Stes, H.; Dockx, L.; Kiekens, F.; D’aes, J.; Copot, C.; Dries, J. Performance and stability of a dynamically controlled EBPR anaerobic/aerobic granular sludge reactor. Bioresour. Technol. 2019, 280, 151-157. [CrossRef]

87. Pronk, M.; de Kreuk, M.K.; de Bruin, B.; Kamminga, P.; Kleerebezem, R.; van Loosdrecht, M.C.M. Full scale performance of the aerobic granular sludge process for sewage treatment. Water Res. 2015, 84, 207-217. [CrossRef]

88. Sguanci, S.; Lubello, C.; Caffaz, S.; Lotti, T. Long-term stability of aerobic granular sludge for the treatment of very low-strength real domestic wastewater. J. Clean Prod. 2019, 222, 882-890. [CrossRef]

89. Di Iaconi, C.; Eusebi, A.L.; De Sanctis, M.; Battistoni, P.; Mininni, G. Two advanced biological approaches for sludge minimization from municipal wastewater treatment. Desalin. Water Treat. 2016, 57, 14414-14423. [CrossRef]

90. Di Iaconi, C.; Del Moro, G.; Bertanza, G.; Canato, M.; Laera, G.; Heimersson, S.; Svanström, M. Upgrading small wastewater treatment plants with the sequencing batch biofilter granular reactor technology: Techno-economic and environmental assessment. J. Clean Prod. 2017, 148, 606-615. [CrossRef] 
91. Di Iaconi, C.; De Sanctis, M.; Rossetti, S.; Ramadori, R. SBBGR technology for minimising excess sludge production in biological processes. Water Res. 2010, 44, 1825-1832. [CrossRef] [PubMed]

92. Di Iaconi, C.; De Sanctis, M.; Lopez, A. A single-stage biological process for municipal sewage treatment in tourist areas. J. Environ. Manag. 2014, 144, 34-41. [CrossRef] [PubMed]

93. De Bruin, L.M.M.; de Kreuk, M.K.; van der Roest, H.F.R.; Uijterlinde, C.; van Loosdrecht, M.C.M. Aerobic granular sludge technology: An alternative to activated sludge? Water Sci. Technol. 2004, 49, 1-7. [CrossRef] [PubMed]

94. Semblante, G.U.; Hai, F.I.; Ngo, H.H.; Guo, W.; You, S.-J.; Price, W.E.; Nghiem, L.D. Sludge cycling between aerobic, anoxic and anaerobic regimes to reduce sludge production during wastewater treatment: Performance, mechanisms, and implications. Bioresour. Technol. 2014, 155, 395-409. [CrossRef] [PubMed]

95. Wei, Y.; Van Houten, R.T.; Borger, A.R.; Eikelboom, D.H.; Fan, Y. Minimization of excess sludge production for biological wastewater treatment. Water Res. 2003, 37, 4453-4467. [CrossRef]

96. Pajdak-Stós, A.; Sobczyk, M.; Fiałkowska, E.; Kocerba-Soroka, W.; Fyda, J. The effect of three different predatory ciliate species on activated sludge microfauna. Eur. J. Protistol. 2017, 58, 87-93. [CrossRef]

97. Kalová, M.; Borkovcová, M. Voracious larvae Hermetia illucens and treatment of selected types of biodegradable waste. Acta Univ. Agric. Silvic. Mendelianae. Brun. 2013, 61,77-83. [CrossRef]

98. Guo, W.-Q.; Yang, S.-S.; Xiang, W.-S.; Wang, X.-J.; Ren, N.-Q. Minimization of excess sludge production by in-situ activated sludge treatment processes-A comprehensive review. Biotechnol. Adv. 2013, 31, 1386-1396. [CrossRef] [PubMed]

99. Yoon, S.-H.; Kim, H.-S.; Yeom, I.-T. The optimum operational condition of membrane bioreactor (MBR): Cost estimation of aeration and sludge treatment. Water Res. 2004, 38, 37-46. [CrossRef] [PubMed]

100. Su, X.; Tian, Y.; Sun, Z.; Lu, Y.; Li, Z. Performance of a combined system of microbial fuel cell and membrane bioreactor: Wastewater treatment, sludge reduction, energy recovery and membrane fouling. Biosens Bioelectron. 2013, 49, 92-98. [CrossRef] [PubMed]

101. Pretel, R.; Robles, A.; Ruano, M.V.; Seco, A.; Ferrer, J. The operating cost of an anaerobic membrane bioreactor (AnMBR) treating sulphate-rich urban wastewater. Sep. Purif. Technol. 2014, 126, 30-38. [CrossRef]

102. Collivignarelli, M.C.; Abbà, A.; Castagnola, F.; Bertanza, G. Minimization of municipal sewage sludge by means of a thermophilic membrane bioreactor with intermittent aeration. J. Clean Prod. 2017, 143, 369-376. [CrossRef]

103. Di Iaconi, C.; Del Moro, G.; Lopez, A.; De Sanctis, M.; Ramadori, R. Municipal wastewater treatment by a periodic biofilter with granular biomass. Water Sci. Technol. 2008, 58, 2395-2401. [CrossRef] [PubMed]

104. Chiavola, A.; Sirini, P.; Cecili, S. Technical and experimental evaluation of an innovative decentralized technology for the municipal wastewater treatment in the city of Rome. Water Sci. Technol. 2010, 62, 956-962. [CrossRef]

105. Mosquera-Corral, A.; Val del Río, Á.; Moralejo-Gárate, H. The aerobic granulation as an alternative to conventional activated sludge process. In Sewage Treatment Plants: Economic Evaluation of Innovative Technologies for Energy Efficiency; IWA Publishing: London, UK, 2015; pp. 95-114.

106. Ghyoot, W.; Verstraete, W. Reduced sludge production in a two-stage membrane-assisted bioreactor. Water Res. 2000, 34, 205-215. [CrossRef]

107. Mutsakatira, E.; Buckley, C.A.; Mercer, S.J. Potential use of the black soldier fly larvae in faecal sludge management: A study in Durban, South Africa. In Proceedings of the 41st WEDC International Conference "Transformation towards sustainable and resilient wash service", Egerton University, Nakuru, Kenya, 9-13 July 2018; paper 2994. pp. 1-7.

108. Gupta, R.; Garg, V. Stabilization of primary sewage sludge during vermicomposting. J. Hazard Mater. 2008, 153, 1023-1030. [CrossRef]

109. Werther, J.; Ogada, T. Sewage sludge combustion. Prog. Energy Combust. Sci. 1999, 25, 55-116. [CrossRef]

110. Samolada, M.C.; Zabaniotou, A.A. Comparative assessment of municipal sewage sludge incineration, gasification and pyrolysis for a sustainable sludge-to-energy management in Greece. Waste Manag. 2014, 34, 411-420. [CrossRef] [PubMed]

111. Jayaraman, K.; Gökalp, I. Pyrolysis, combustion and gasification characteristics of miscanthus and sewage sludge. Energy Convers. Manage. 2015, 89, 83-91. [CrossRef]

112. Fonts, I.; Gea, G.; Azuara, M.; Ábrego, J.; Arauzo, J. Sewage sludge pyrolysis for liquid production: A review. Renew. Sustain. Energy Rev. 2012, 16, 2781-2805. [CrossRef] 
113. Fytili, D.; Zabaniotou, A. Utilization of sewage sludge in EU application of old and new methods-A review. Renew. Sustain. Energy Rev. 2008, 12, 116-140. [CrossRef]

114. Huang, L.; Liu, J.; He, Y.; Sun, S.; Chen, J.; Sun, J.; Chang, K.; Kuo, J.; Ning, X. Thermodynamics and kinetics parameters of co-combustion between sewage sludge and water hyacinth in $\mathrm{CO}_{2} / \mathrm{O}_{2}$ atmosphere as biomass to solid biofuel. Bioresour. Technol. 2016, 218, 631-642. [CrossRef] [PubMed]

115. Inguanzo, M.; Dominguez, A.; Menéndez, J.A.; Blanco, C.G.; Pis, J.J. On the pyrolysis of sewage sludge: the influence of pyrolysis conditions on solid, liquid and gas fractions. J. Anal. Appl. Pyrolysis 2002, 63, 209-222. [CrossRef]

116. Magdziarz, A.; Werle, S. Analysis of the combustion and pyrolysis of dried sewage sludge by TGA and MS. Waste Manag. 2014, 34, 174-179. [CrossRef]

117. Agrafioti, E.; Bouras, G.; Kalderis, D.; Diamadopoulos, E. Biochar production by sewage sludge pyrolysis. J. Anal. Appl. Pyrolysis. 2013, 101, 72-78. [CrossRef]

118. Chen, T.; Zhang, Y.; Wang, H.; Lu, W.; Zhou, Z.; Zhang, Y.; Ren, L. Influence of pyrolysis temperature on characteristics and heavy metal adsorptive performance of biochar derived from municipal sewage sludge. Bioresour. Technol. 2014, 164, 47-54. [CrossRef]

119. Freda, C.; Cornacchia, G.; Romanelli, A.; Valerio, V.; Grieco, M. Sewage sludge gasification in a bench scale rotary kiln. Fuel 2018, 212, 88-94. [CrossRef]

120. Lee, J.E.; Lee, J.K.; Choi, H.K. Filter Press for Electrodewatering of Waterworks Sludge. Dry Technol. 2007, 25, 1985-1993. [CrossRef]

121. Li, Q.; Lu, X.; Guo, H.; Yang, Z.; Li, Y.; Zhi, S.; Zhang, K. Sewage sludge drying method combining pressurized electro-osmotic dewatering with subsequent bio-drying. Bioresour. Technol. 2018, 263, 94-102. [CrossRef] [PubMed]

122. Zhang, H.; Rigamonti, L.; Visigalli, S.; Turolla, A.; Gronchi, P.; Canziani, R. Environmental and economic assessment of electro-dewatering application to sewage sludge: A case study of an Italian wastewater treatment plant. J. Clean Prod. 2019, 210, 1180-1192. [CrossRef]

123. Gronchi, P.; Canziani, R.; Brenna, A.; Visigalli, S.; Colominas, C.; Montalà, F.; Cot, V.; Stradi, A.; Ferrari, G.; Diaz, C.; et al. Electrode surface treatments in sludge electro-osmosis dewatering. Mater. Manuf. Process. 2017, 32, 1265-1273. [CrossRef]

124. Mahmoud, A.; Hoadley, A.F.A.; Citeau, M.; Sorbet, J.M.; Olivier, G.; Vaxelaire, J.; Olivier, J. A comparative study of electro-dewatering process performance for activated and digested wastewater sludge. Water Res. 2018, 129, 66-82. [CrossRef]

125. Qian, X.; Zhou, X.; Wu, J.; Liu, C.; Wei, Y.; Liu, J. Electro-dewatering of sewage sludge: Influence of combined action of constant current and constant voltage on performance and energy consumption. Sci. Total Environ. 2019, 667, 751-760. [CrossRef] [PubMed]

126. Gronchi, P.; Canziani, R.; Brenna, A.; Visigalli, S. Evaluation of electrode surface treatments in slugde Electro-Osmosis dewatering. In Proceedings of the XXX International Conference on Surface Modification Technologies (SMT30), Milan, Italy, 29 June-1 July 2016; pp. 1-14.

127. Barton, W.A.; Miller, S.A.; Veal, C.J. The electrodewatering of sewage sludges. Dry Technol. 1999, 17, 498-522. [CrossRef]

128. Lv, H.; Liu, D.; Zhang, Y.; Yuan, D.; Wang, F.; Yang, J.; Wu, X.; Zhang, W.; Dai, X. Effects of temperature variation on wastewater sludge electro-dewatering. J. Clean Prod. 2019, 214, 873-880. [CrossRef]

129. Zhang, Y.; Cao, M.; Lv, H.; Wei, J.; Gu, Y.; Liu, D.; Zhang, W.; Ryan, M.P.; Wu, X. Electrodeposited nanometer-size $\mathrm{IrO}_{2} / \mathrm{Ti}$ electrodes with $0.3 \mathrm{mg} \mathrm{IrO} \mathrm{cm}^{-2}$ for sludge dewatering electrolysers. Electrochim. Acta. 2018, 265, 507-513. [CrossRef]

130. Manara, P.; Zabaniotou, A. Towards sewage sludge based biofuels via thermochemical conversion-A review. Renew. Sustain. Energy Rev. 2012, 16, 2566-2582. [CrossRef]

131. Amorim, C.L.; Moreira, I.S.; Ribeiro, A.R.; Santos, L.H.M.L.M.; Delerue-Matos, C.; Tiritan, M.E.; Castro, P.M.L. Treatment of a simulated wastewater amended with a chiral pharmaceuticals mixture by an aerobic granular sludge sequencing batch reactor. Int. Biodeterior. Biodegradation. 2016, 115, 277-285. [CrossRef]

132. Spinosa, L. Sludge Minimisation: A Fundamental Part of Wastewater Management; IWA Publishing: London, UK, 2010. 
133. Bertanza, G.; Canato, M.; Heimersson, S.; Laera, G.; Salvetti, R.; Slavik, E.; Svanström, M. Techno-economic and environmental assessment of sewage sludge wet oxidation. Environ. Sci. Pollut. Res. 2015, 22, 7327-7338. [CrossRef] [PubMed]

134. Tomei, M.C.; Bertanza, G.; Canato, M.; Heimersson, S.; Laera, G.; Svanström, M. Techno-economic and environmental assessment of upgrading alternatives for sludge stabilization in municipal wastewater treatment plants. J. Clean Prod. 2016, 112, 3106-3115. [CrossRef]

135. EAA Technical assessment of the implementation of Council Directive concerning Urban Waste Water Treatment (91/271/EEC) Final version. Environment Agency of Austria, 2015. Available online: http://ec.europa.eu/environment/water/water-urbanwaste/implementation/implem_report_2016/8th\% 20Technical\%20assessment \%20of\%20information\%20on \%20the \%20implementation \%20of\%20Council\% 20Directive\%2091-271-EEC.pdf (accessed on 25 June 2019).

136. Kalderis, D.; Aivalioti, M.; Gidarakos, E. Options for sustainable sewage sludge management in small wastewater treatment plants on islands: The case of Crete. Desalination 2010, 260, 211-217. [CrossRef]

(C) 2019 by the authors. Licensee MDPI, Basel, Switzerland. This article is an open access article distributed under the terms and conditions of the Creative Commons Attribution (CC BY) license (http://creativecommons.org/licenses/by/4.0/). 